\title{
Chitosan: An Overview of Its Properties and Applications
}

\author{
Inmaculada Aranaz ${ }^{1,2}{ }^{\circledR}$, Andrés R. Alcántara ${ }^{1}\left(\mathbb{D}\right.$, Maria Concepción Civera ${ }^{1}\left(\mathbb{C}\right.$, Concepción Arias ${ }^{1}$, \\ Begoña Elorza ${ }^{1}$, Angeles Heras Caballero ${ }^{1,2}$ and Niuris Acosta 1,2,*(D) \\ 1 Departmento de Química en Ciencias Farmacéuticas, Universidad Complutense de Madrid, \\ 28040 Madrid, Spain; iaranaz@ucm.es (I.A.); andalcan@ucm.es (A.R.A.); mccivera@ucm.es (M.C.C.); \\ carias@ucm.es (C.A.); belorza@ucm.es (B.E.); aheras@farm.ucm.es (A.H.C.) \\ 2 Instituto Pluridisciplinar, Universidad Complutense de Madrid, Paseo Juan XXIII, n 1, 28040 Madrid, Spain \\ * Correspondence: facosta@ucm.es; Tel.: +34-913-943-284
}

check for updates

Citation: Aranaz, I.; Alcántara, A.R.; Civera, M.C.; Arias, C.; Elorza, B.; Heras Caballero, A.; Acosta, N. Chitosan: An Overview of Its Properties and Applications. Polymers 2021, 13, 3256. https://doi.org/ 10.3390/polym 13193256

Academic Editors: Rebeca Hernandez Velasco,

David Mecerreyes, Rafael Antonio Balart Gimeno, Ana

María Díez-Pascual, Vicente Compañ Moreno and Angels Serra

Received: 30 August 2021

Accepted: 22 September 2021

Published: 24 September 2021

Publisher's Note: MDPI stays neutral with regard to jurisdictional claims in published maps and institutional affiliations.

Copyright: (c) 2021 by the authors. Licensee MDPI, Basel, Switzerland. This article is an open access article distributed under the terms and conditions of the Creative Commons Attribution (CC BY) license (https:/ / creativecommons.org/licenses/by/ $4.0 /)$.

\begin{abstract}
Chitosan has garnered much interest due to its properties and possible applications. Every year the number of publications and patents based on this polymer increase. Chitosan exhibits poor solubility in neutral and basic media, limiting its use in such conditions. Another serious obstacle is directly related to its natural origin. Chitosan is not a single polymer with a defined structure but a family of molecules with differences in their composition, size, and monomer distribution. These properties have a fundamental effect on the biological and technological performance of the polymer. Moreover, some of the biological properties claimed are discrete. In this review, we discuss how chitosan chemistry can solve the problems related to its poor solubility and can boost the polymer properties. We focus on some of the main biological properties of chitosan and the relationship with the physicochemical properties of the polymer. Then, we review two polymer applications related to green processes: the use of chitosan in the green synthesis of metallic nanoparticles and its use as support for biocatalysts. Finally, we briefly describe how making use of the technological properties of chitosan makes it possible to develop a variety of systems for drug delivery.
\end{abstract}

Keywords: chitosan; chitin; biological activity; drug delivery; antioxidant; antimicrobial; metallic nanoparticles; biocatalysis

\section{Introduction}

Chitin and its deacetylated derivative, chitosan, are a family of linear polysaccharides composed of varying amounts of $(\beta 1 \rightarrow 4)$ linked residues of $N$-acetyl-2 amino-2-deoxyD-glucose (glucosamine, GlcN) and 2-amino-2-deoxy-D-glucose ( $N$-acetyl-glucosamine, GlcNAc) residues. Chitosan is soluble in aqueous acidic media via primary amine protonation. In contrast, in chitin, the number of acetylated residues is high enough to prevent the polymer for dissolving in aqueous acidic media.

Chitin is a very abundant biopolymer that can be found in the exoskeleton of crustacea, insect's cuticles, algae and in the cell wall of fungi. Chitosan is less frequent in nature occurring in some fungi (Mucoraceae). Historically, commercial chitosan samples were mainly produced from chemical deacetylation of chitin from crustacean sources. More recently, chitosan from fungi is gaining interest in the market, driven by vegan demands. Moreover, these samples are better controlled in terms of low viscosity and exhibit a very high deacetylation degree [1]. Production from insect cuticles is also gaining interest, driven by the increased interest in protein production from these sources.

The interest in chitin and chitosan relies on the myriad biological and technological properties exhibited by these polymers (Table 1). However, these properties are tightly related to the physicochemical properties of the polymers (mainly molecular weight and acetylation degree) [2]. Therefore, when working with chitin and chitosan a good and completed polymer characterization is mandatory. Several methodologies have been described to characterize chitin, chitosan and chitooligosaccharides, a description of which is far from the objective of this paper-but for interested readers, we recommend publications [3,4]. 
Table 1. The main properties of chitin and chitosan.

\begin{tabular}{cc}
\hline Property/Activity & Reference \\
\hline Mucoadhesive & {$[5,6]$} \\
Anti-inflammatory & {$[7]$} \\
Antioxidant & {$[8]$} \\
Antimicrobial & {$[9]$} \\
Antifungal & {$[10]$} \\
Antihyperglycemic & {$[11]$} \\
Antitumoral & {$[7-12]$} \\
Wound healing & {$[13]$} \\
\hline
\end{tabular}

Chitosan is the only polycation in nature and its charge density depends on the degree of acetylation and $\mathrm{pH}$ of the media. The solubility of the polymer depends on the acetylation degree and molecular weight. Chitosan oligomers are soluble over a wide $\mathrm{pH}$ range, from acidic to basic ones (i.e., physiological pH 7.4). On the contrary, chitosan samples with higher $\mathrm{Mw}$ are only soluble in acidic aqueous media even at high deacetylation degrees. This lack of solubility at neutral and basic $\mathrm{pH}$ has hindered the use of chitosan in some applications under neutral physiological conditions (i.e., $\mathrm{pH}$ 7.4). This is the reason why a great number of chitosan derivatives with enhanced solubility have been synthetized.

In 2019, the global chitosan market size was valued at USD 6.8 billion, and it is expected to expand at a revenue based CAGR of $24.7 \%$ between 2020 and 2027. The drivers for the market's growth are the increasing application of the polymer in water treatment and several high-value industries such as the pharmaceutical, biomedical, cosmetics and food industries [14]. Some of the interest areas identified include the modification of the polymers to extend their applicability; knowledge of the mechanisms involved in the biological activity of chitosan, chitosan derivatives and chitooligosaccharides; and the in-depth study of chitosanolytic and chitinolytic enzymes presented in different microorganisms [15].

This review aims to provide readers with a general overview of the state of the art of chitosan science, covering different aspects such as polymer chemistry, biological and technological properties and applications in drug delivery and as a biocatalyst.

\section{Technological Chitosan Properties}

\subsection{Solubility}

Chitosan is produced by deacetylation of chitin; in this process, some $N$-acetylglucosamine moieties are converted into glucosamine units. The presence of large amounts of protonated $-\mathrm{NH}_{2}$ groups on the chitosan structure accounts for its solubility in acid aqueous media since its pKa value is approximately 6.5 [16]. When around $50 \%$ of all amino groups are protonated, chitosan becomes soluble [17].

Chitosan solubility depends on different factors such as polymer molecular weight, degree of acetylation, $\mathrm{pH}$, temperature, and polymer crystallinity. Homogeneous deacetylation (alkali treatment, $0^{\circ} \mathrm{C}$ ) of chitin permits the production of polymers soluble in aqueous acetic acid solutions with DD as low as $28 \%$, with this value never being reached under heterogeneous deacetylation (alkali treatment, high temperatures). Moreover, with a DD of $49 \%$, the samples are soluble in water. This behaviour is explained by the fact that homogeneous deacetylation leads to an increase in the number of glucosamine units and a modification in the crystalline structure of the polymer. Depending on polymer DD, these modifications range from a reduction in crystal size and crystal perfection to the presence of a new crystal structure close to $\beta$-chitin [18]. Sogias et al. [19] studied the role of crystallinity and inter- or intramolecular forces on chitosan solubility; in this work, a parent chitosan sample was half re-acetylated with anhydride acetic or fully $N$-deacetylated under homogeneous conditions. After reacetylation, the solubility of the polymer was expanded until $\mathrm{pH}$ 7.4, while a slight reduction in the solubility range of the fully deacetylated chitosan was determined. The lower solubility was explained due to the increase in the polymer crystallinity after deacetylation, which offsets the effect of the increase in 
glucosamine moieties. On the contrary, a reduction in the crystallinity was observed in the half-acetylated sample. The use of hydrogen bond disruptors such as urea or guanidine hydrochloride also alters the solubility window of chitosan. In fact, by a combination of chemical and physical disruption of the hydrogen bonds, broad solubility is achieved.

\subsection{Viscosity}

The viscosity of polymers is a parametre of great interest from the technological point of view since highly viscous solutions are difficult to manage. Moreover, viscometry is a powerful tool for determining chitosan's molecular weight, as it is a simple and rapid method even though it is not an absolute method, therefore requiring the determination of constants that are specific to the solvent. The average molecular weight is determined by the Mark-Houwink-Sakurada equation, which relates this parametre with the intrinsic viscosity:

$$
\eta=\mathrm{KM}_{\mathrm{v}}{ }^{\alpha}
$$

where $\mathrm{K}$ and $\alpha$ are constants that must be determined experimentally. Several values of $\mathrm{K}$ and $\alpha$ have been reported depending on the solvent composition, $\mathrm{pH}$, and ionic strength [20]. Chitosan viscosity depends on the molecular weight of the polymer and deacetylation degree and decreases as the molecular weight of chitosan is reduced. In fact, viscosity can be used to determine the stability of the polymer in solution, as a reduction is observed during polymer storage due to polymer degradation [21]. Shear viscosity increases with chitosan deacetylation degree. The shear viscosity at the same rate was studied in two samples with different deacetylation degrees (91\% vs. $75 \%$ ) and represented versus intrinsic viscosity [22]; it was reported that shear viscosity was larger for those samples with the highest deacetylation degree; when the curves were evaluated, straight lines were observed in both chitosan samples This is explained due to the nature of chitosan, as this polymer is a cationic polyelectrolyte because of the amine protonation in acidic media. Therefore, the higher the DD, the larger chain expansion is expected, as more glucosamine units are found in the polymer chain, leading to a greater charge density in this sample. In order to modulate chitosan viscosity, the addition of different co-solvents has been evaluated; in this sense, Kassai et al. [20] studied the effect of the addition of isopropanol and ethanol to a chitosan solution in $1 \%$ acetic acid, reporting that the presence of the cosolvents decreased the intrinsic viscosity of the polymer.

\section{Chemistry of Chitosan}

As seen in Figure 1, the reactive groups found in chitosan are a primary amino group (C2) and primary and secondary hydroxyl groups (C6, C3). Glycosidic bonds and the acetamide group can also be considered functional groups. These functional groups allow for a great number of modifications, producing polymers with new properties and behaviours.

Chitosan derivatives have been produced, aiming to improve chitosan's properties, such as solubility or biodegradability, or to introduce new functions or properties. For instance, solubility has been improved in water aqueous media by deacetylation, depolymerization, or quaternisation among other processes [23]. New chitosan activities have been reported after its modification, for example, 6-O-sulphated chitosan promotes neuronal differentiation while phosphorylated chitosan inhibits corrosion [24,25]. 


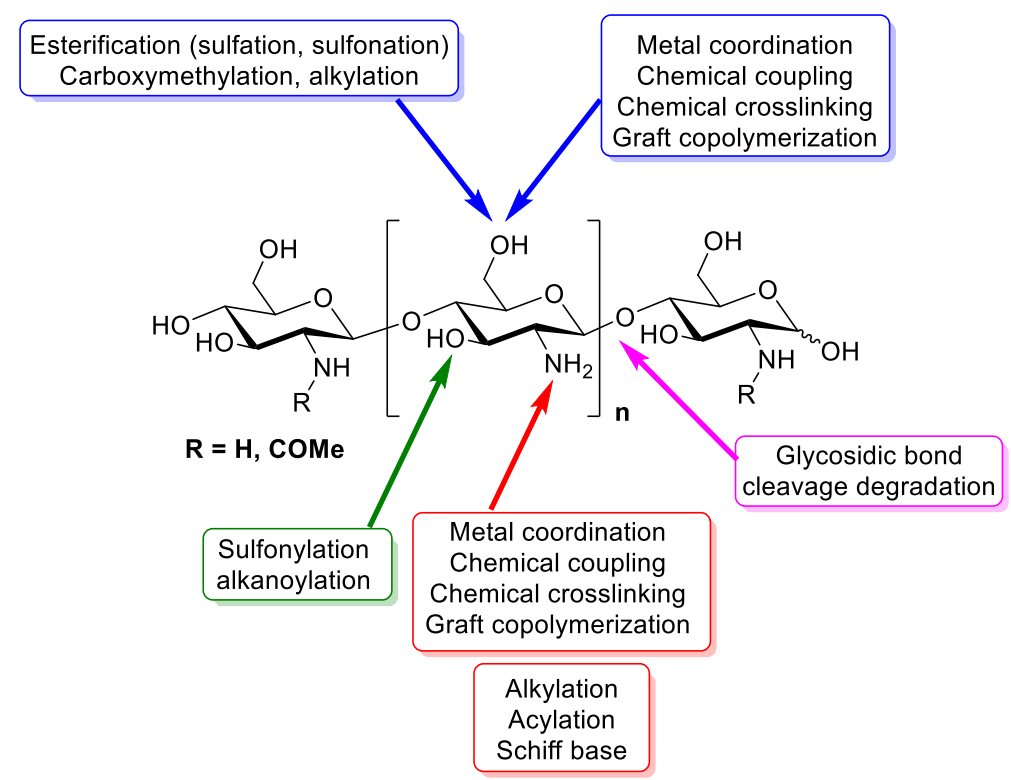

Figure 1. Functional groups in chitosan's structure that are able to be chemically modified.

The field of chitosan chemistry is wide, and in this review, we want to focus on two types of processes, chitosan phosphorylation and chitosan degradation. Our group has participated in the development of a phosphorylated derivative via a simple method in which chitosan and phosphorus acid are mixed at the same ratio and formaldehyde is added at $70{ }^{\circ} \mathrm{C}[26]$ (Figure 2).
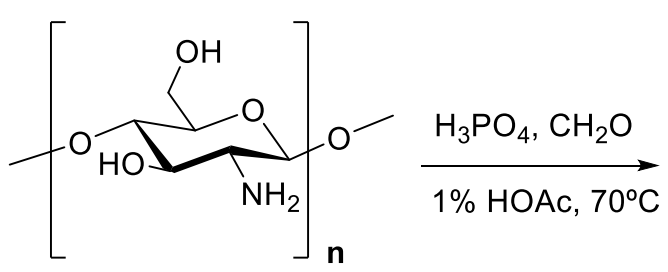

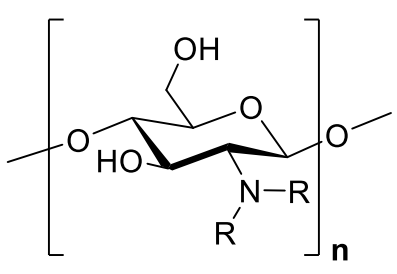

$\mathrm{R}=\mathrm{H}$ or $\mathrm{CH}_{2} \mathrm{PO}_{3} \mathrm{H}_{2}$

Figure 2. Scheme of phosphorylated chitosan derivative synthesis.

This $\mathrm{N}$-methylene phosphonic chitosan is soluble in water and keeps the filmogenic properties of the parent chitosan. With a similar methodology, a soluble in water $\mathrm{N}$ methylenephenyl phosphonic chitosan has been produced [27]. Additionally, the surfactant derivative $\mathrm{N}$-lauryl- $\mathrm{N}$-methylene phosphonic chitosan was produced via $\mathrm{N}$-alkylation of $\mathrm{N}$-methylene phosphonic chitosan [28]. This derivative has a lower solubility in aqueous media compared to $\mathrm{N}$-methylene phosphonic chitosan but better solubility in organic media and forms micelles. $\mathrm{N}$-methylene phosphonic $\mathrm{N}$-methylene carboxylic chitosan has been obtained in water-soluble form using $\mathrm{N}$-methylene phosphonic chitosan and glyoxylic acid. The polymer maintains the filmogenic properties of parent chitosan and, because of the presence of multidentate ligands, its use as a bivalent metal chelating agent is proposed [29].

Although the use of chitosan as a gene carrier has been reported, the use of this biopolymer for this application is limited due to a relatively low transgenic efficacy. Phosphorylated derivatives have shown better performance (transfection was improved 100fold) and therefore are more suitable than chitosan to this end. Moreover, phosphorylated derivatives also exhibit and improve metal ion chelating activity when compared to the parent chitosan [30,31].

Due to the presence of cleavage glycosidic bonds, it is possible to degrade chitosan, thus reducing its molecular weight. As previously mentioned, the control of chitosan 
depolymerization (polymer size) permits us to control some properties such as solubility or viscosity. Moreover, the biological and technological properties of chitosan are related to size, among other properties as previously reviewed [2]. Chitosan degradation can occur through different mechanisms such as acid hydrolysis, oxidative-reductive or nitrous acid depolymerization, ultrasonic degradation, or enzymatic degradation using specific and non-specific enzymes. Chitosan has four types of glycosidic linkages -D-D-, -A-A-, -A-D- and -D-A- (where A and D denote $\mathrm{N}$-acetylglucosamine and glucosamine monomers, respectively). Depending on the process, there is a prevalence in the breakage of certain linkages and therefore different samples can be produced from the same parent chitosan by selecting different methodologies. Chemical and physical methods are less selective than enzymatic ones for producing specific patterns due to enzyme-specific recognition but by controlling the parametres of the process some control over the composition can be gained.

Ultrasonic degradation of chitosan does not affect the degree of acetylation or polydispersity of the recovered polymers allowing for the moderate degradation of the polymer [32]. The rate of degradation depends on the acetylation degree of the parent chitosan and not on the initial molecular weight [33].

Hydrogen peroxide produces random degradation of chitosan in a faster manner than ultrasonic methodologies, producing a significant number of monomers and chitooligosaccharides, the composition of which depends on the temperature and $\mathrm{H}_{2} \mathrm{O}_{2}$ concentration [34]. Nitrous acid depolymerization can be considered somewhat specific since $\mathrm{HNO}_{2}$ attacks the primary amine in glucosamine and subsequently the cleavage of the glycosidic bonds occurs. That is, only the glycosidic linkage following a $D$-unit can be cleaved [35]. The chemical processes yield large amounts of monomers ( $D$-glucosamine) and when the intended final products are chitooligosaccharides rather than low molecular weight chitosan, the yields are low [36]. $\mathrm{HNO}_{2}$ provokes the formation of 2,5-anhydro- $D$ mannose at the new reducing end, which may be considered a disadvantage of this acid. When chitosan is degraded by $\mathrm{HCl}$, the polymer not only suffers the hydrolysis of the $\mathrm{O}$-glycosidic linkage between residues but also the $\mathrm{N}$-acetyl linkage can be hydrolyzed but at a lower rate. The hydrolysis rate of $\mathrm{D}-\mathrm{D}$ and $\mathrm{D}-\mathrm{A}$ glycosidic linkages is lower than the hydrolysis of A-A and A-D, therefore the reducing ends are dominated by acetylated units [37]. By using a controlled precipitation method with methanol, it has been possible to obtain chitooligosaccharides with DPs up to 16 with few low molecular weight oligomers with a good yield [38].

The specific enzymatic degradation of chitosan occurs with a family of enzymes named chitosanases (EC 3.2.1.132) and chitinases (EC 3.2.1.14). Chitosanases are glycosyl hydrolases that catalyse the endo hydrolysis of $\beta-1,4$-glycosidic bonds of partially acetylated chitosan to release chitosan oligosaccharides (COS) with little monomer release [39]. Chitosanase specifically hydrolyses chitosan by cleavage of glycosidic bonds with a -DD.DApattern or a -DD.DD-pattern. Chitinases, which occur in families GH18 and GH 19, are glycosyl hydrolases that can degrade both A-A and A-D linkages and show no activity against D-D linkages. Chitinases can be classified into two major categories (endochitinases and exochitinases) according to their mode of action [40].

Non-specific enzymes, also called promiscuous enzymes, are also able to degrade chitosan. These enzymes belong to the protease, lipase, cellulase, and hemicellulase families, among others. Lysozyme is one of the most studied due to its relationship with polymer biodegradation. this enzyme is a protease that hydrolyses chitosan by cleavage of glycosidic bonds with A-A-A-A- pattern or A-A-A-D-pattern, while A-D-A-pattern or D-D-A-A are not or very slowly hydrolysed by lysozyme [14,17]. Apart from the previously mentioned lysozyme, other proteolytic enzymes such as pepsin, papain and pronase caused chitosan depolymerization, rendering low molecular chitosans (4-10 kDa) as the main products and chitooligosaccharides and monomers in smaller amounts. Results indicated that papain and pepsin had a similar action pattern. Both enzymes decreased LMWC acetylation degree when compared to the parent chitosan; DP 2-6 were detected in the supernatant monomers (D and A) and oligomers. Pronase showed different behaviour 
since no glucosamine was detected. It showed selectivity through A-A and A-D, resulting in products having A monomers at the reducing end [41].

Neutral protease degraded chitosan in a manner dependent on the deacetylation degree. The higher the DD, the higher the Km and the lower the Vmax. During degradation, a reduction in the DD of the recovered LMW chitosans was observed. An analysis of the partially hydrolysed chitosan revealed that the enzyme degraded D-D and A-D $\beta-1,4-$ glycosidic linkages, producing a mixture of hetero oligosaccharides carrying an A residue at the reducing end [42]. The same authors have studied the effect of the chitosan molecular weight in the enzymatic activity since this parametre affects its chain flexibility in solution, which in turn may affect its affinity for the enzyme in hydrolysis reactions. Their results showed a lower affinity of the enzyme with a slower degradation rate when high molecular weight chitosan samples were tested [43].

Hemicellulase, an enzyme related to the degradation of hemicellulose, has proven its ability to reduce chitosan molecular weight in a manner that depends on the deacetylation degree of the chitosan, rendering lower molecular weight samples when a chitosan sample with a DD of $85 \%$ was tested. Dimers, trimers, tetramers, pentamers and hexamers were observed after 4 hours of reaction, and the enzyme was considered endo-acting since no $\mathrm{N}$-acetylglucosamine was detected [44].

Lipases have also proved their ability to hydrolysate chitosan, although the degradation rates are slower than the ones reported by other enzymes such as proteases or hemicellulose. Controlling reaction temperature, a commercial lipase rendered low molecular weight samples or chitooligosaccharides $[45,46]$. This lipase acted following both exo and endo cleavage mode. The presence of $\mathrm{D}$ end products indicates that it acted on chitosan in an exo-type mode while the sharp reduction in viscosity during the hydrolysis indicates that an endo splitting occurred in the initial hydrolysis stage. Therefore, by controlling the reaction time the final products can be led to oligomers with high DP or monomers. The polymer polydispersity depended on the used enzyme, lipase from wheat germ rendered samples with very wide molecular weight while lipase from $R$. japonicus exhibited better control over polydispersity [47].

The data previously showed that it is possible to somehow select the degradation products (LMW chitosans or oligosaccharides) by selecting the appropriate methodology (Table 2). As we can see in some sections of this review, specific biological and technological behaviour of chitosan degradation products depends not only on the method (physical, chemical, or enzymatic) selected to degrade the chitosan but also on the type of chemical or enzyme used for these processes. This effect is more related to the degraded polymer pattern rather than to the size or acetylation degree of the samples.

Table 2. The main products produced in the enzymatic degradation of chitosan.

\begin{tabular}{cc}
\hline Enzyme & Main Product \\
\hline Chitosanase & Oligomers DP 2-3 \\
Hemicellulase & Dimers, trimers, tetramers, pentamers and hexamers \\
Pepsine & Glucosamine, N-acetylglucosamine oligomers with DP 2-6 \\
Pronase & $4-10 \mathrm{kDa}$ \\
Papain & Glucosamine, N-acetylglucosamine oligomers with DP 2-6 \\
Lipase & High DP \\
\hline
\end{tabular}

DP: depolymerization degree.

\section{Biological Properties}

Chitin, chitosan, oligosaccharides, and derivatives exert many biological activities including antitumoral, antimicrobial, antioxidant, and anti-inflammatory activities, which could be used as therapeutic polymers. It is remarkable that up today chitosan and chitosan hydrochloride are only accepted as excipients by the regulatory agencies and not as a drug for the treatment of diseases. 


\subsection{Antimicrobial Activity}

Bacterial resistance to antibiotics is a critical public health concern and, therefore, there is an urgency to find alternatives to antibiotics. Chitosan, chitosan derivatives and chitooligosaccharides exert antimicrobial activity against different microorganisms, including bacteria, filamentous fungi, and yeast [48]; some examples of the different microorganisms sensible to chitosan are shown in Table 3. Chitosan seems to have a growth-inhibitory activity since bacteria is able to grow after the polymer is removed from the media. This is of importance since resistant populations might emerge if the cells adapt to chitosan [49].

Table 3. Antimicrobial and antifungal activity of chitosan.

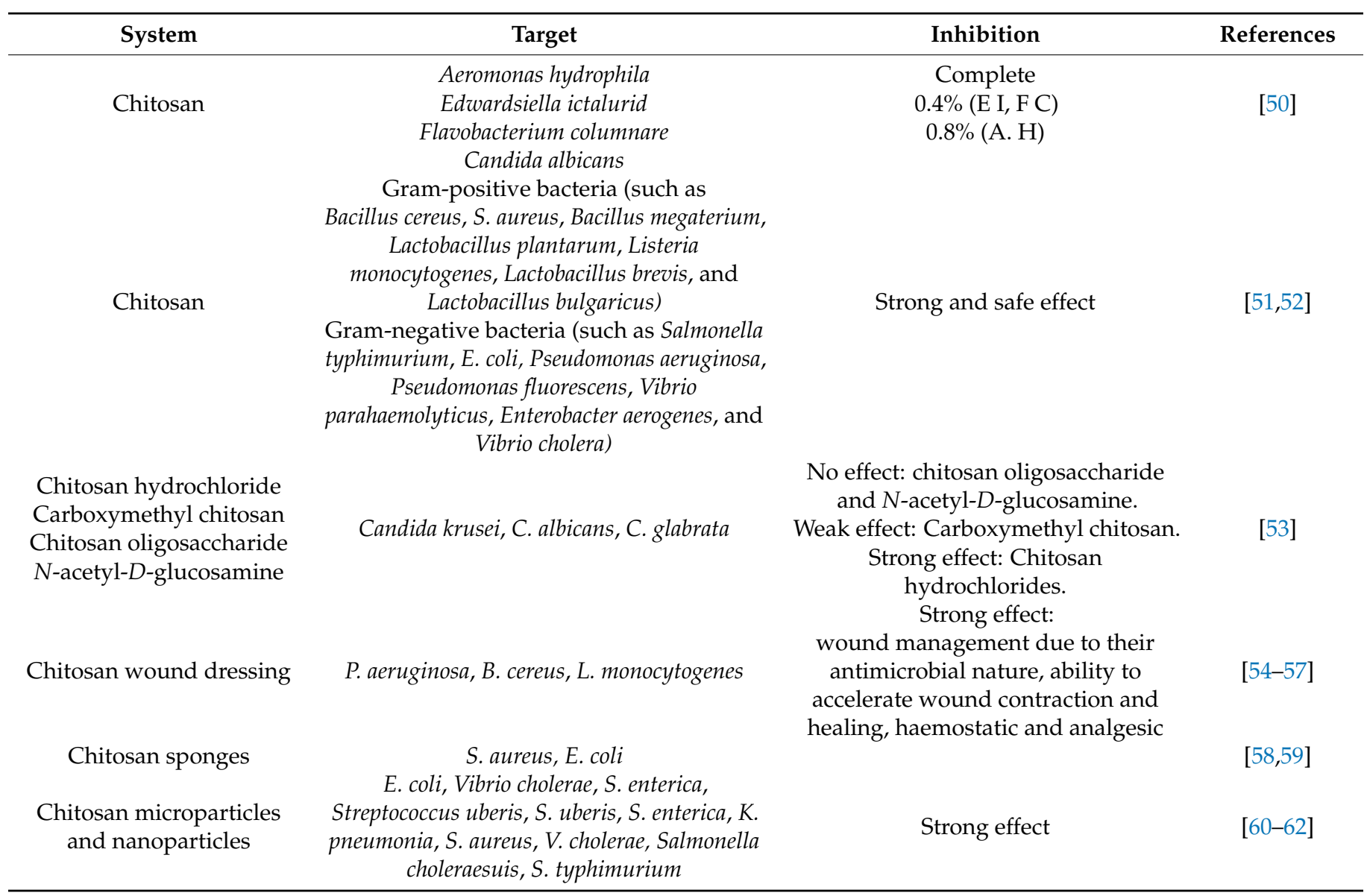

Due to chitosan's poor solubility above $\mathrm{pH}$ 6.5, the use of chitooligosaccharides is under consideration as polycationic biocides since they are soluble in water. Chitosan soluble derivatives such as sulphated chitosan, $\mathrm{N}$-trimethyl chitosan, $\mathrm{N}$-diethylmethyl chitosan or 2,6-diamino chitosan also avoid the use of acidic environments and exert antimicrobial activity [63-65]. This antimicrobial activity has applications in different fields such as the food, textile, or cosmetic industry, among others. Thus, due to the ability of chitosan to form shift bases, some new chitosan derivatives based on heterocyclic moieties have been developed, including pyrazole ring and furanyl, pyridyl, or thiophenyl moieties. Although these derivatives do not show higher solubility in aqueous media, their performance against gram-positive microorganism was improved when compared with the parent chitosan [66].

How these polymers (chitosan, chitooligosaccharides and derivatives) exert their antimicrobial activity is still under discussion. This fact can be explained by taking into account the lack of appropriate polymer characterization, purity issues, the use of different microorganisms, and the lack of methodological uniformity. Some studies point to the 
reduction in cell membrane permeability due to polymer coating on the surface of the cells that blocks cell access to nutrients. This process occurs due to the interaction of $-\mathrm{NH}_{2}$ groups from chitosan chains with -COO- groups on the external cell membranes of microorganisms. Therefore, the antimicrobial activity depends on the acetylation degree. It has also been hypothesized that chitosan can penetrate the cells and block RNA transcription as a result of adsorption with bacterial DNA [9]. Most likely, these mechanisms are not mutually exclusive, and several events are related to cell growth inhibition.

Intrinsic factors affecting the antimicrobial chitosan activity are due to the polymer characteristics such as Mw, acetylation degree, polymer viscosity, or polymer concentration. The solvent used to dissolve the polymer also affects its behaviour. We have observed that typical solvents used to dissolve chitosan such as acetic acid, citric acid, or buffers such as AcOH-NaAc exert some antimicrobial activity per se (unpublished results). Other factors with great impact on the antimicrobial activity are related to the tested microorganism, growth media, $\mathrm{pH}$, temperature, ionic strength, or physiological state of the cells.

The effect of polymer size is controversial. Some studies claim that the antimicrobial activity of chitosan improves with the polymer size and have found that oligosaccharides have lower antimicrobial activity [67-69]. When comparing chitooligosaccharides, those showing higher DP exhibited higher antimicrobial activity [70]. Moreover, Tokura and co-workers reported that chemically produced chitooligosaccharides of 2200 Da not only had no antimicrobial activity but also served as growth accelerators of E. coli, while a sample with $9300 \mathrm{Da}$ inhibited bacterial growth [71]. On the contrary, other studies showed better antimicrobial activity for a lower molecular weight chitosan sample ( $55 \mathrm{kDa})$ than a higher one $(155 \mathrm{kDa})$; in the same study when a sample of $90 \mathrm{kDa}$ was tested a promotion of bacterial growth was observed [72]. In another study, different tendencies were observed depending on the $\mathrm{pH}$ of the media. In acidic $\mathrm{pH}$ conditions, the antimicrobial activity increased with increasing MW. However, at neutral $\mathrm{pH}$, antimicrobial activity increased as the MW decreased [73]. Even so, no trend on the effect of chitosan Mw on antimicrobial activity has been reported [74]. Regarding acetylation degree, it seems that the lower the acetylation degree, the better the antimicrobial activity $[69,74,75]$.

After depolimerization of a chitosan sample (400 kDa, DD 85\%) with hemicellulose, a set of chitosan samples with similar DD and Mw ranging from 130 to $2.8 \mathrm{kDa}$ and a chitooligosacharide sample with $\mathrm{Mw} 1.4$ were produced. Some of these samples were also half-acetylated, furnishing two chitosan samples with Mw of 53 and $18 \mathrm{kDa}$, and some chitoligosaccharides with $\mathrm{Mw}$ of $1.4 \mathrm{kDa}$. Both chitooligosacharides samples and the half-acetylated samples were water soluble, while the others were not soluble in water. All samples were tested against Staphylococcus aureus, Escherichia coli, and Candida albicans. In this study, water soluble chitosans and oligosaccharides did not exhibit antimicrobial activity; in fact, they promoted the growth of C. albicans. Insoluble chitosan samples exhibited antimicrobial activity with the most pronounced effect when medium molecular weight samples were tested (Mw 78-48 kDa) [76].

Our group has studied the antimicrobial activity of low molecular weight chitosans and oligosaccharides produced by enzymatic degradation in order to determine if the polymer pattern has some effect on this activity. Chitooligosaccharides were produced by two different processes; thus, in process P1 chitosan was enzymatically depolymerized with chitosanase, while in process P2 the sample was depolymerized in a two-step process with $\mathrm{HNO}_{2}$ and chitosanase. The samples were tested against E coli and L. monocytogenes. COS from P1 showed a higher capability to inhibit bacterial growth than COS from P2. In both cases, COS were more effective at inhibiting E. coli (Gram-negative) than the Gram-positive L. monocytogenes. Antimicrobial activity depended on the production process and composition and structure of COS. COS produced in a one-step enzymatic procedure showed better antimicrobial activity than those produced in the two-step chemical-enzymatic process even when the samples exhibited similar DA and MW [77]. 


\subsection{Antioxidant Activity}

Antioxidants are gaining interest due to the relationship between oxidative stress and several diseases such as Alzheimer's disease, Parkinson's disease, Huntington's disease, amyotrophic lateral sclerosis, and cancer. Moreover, it is related to complications in other diseases such as diabetes [78-80].

Chitosan contains an amino and several hydroxyl groups, which can react with free radicals exhibiting scavenging ability. Some chitosan derivatives such as chitosan sulphates or N-2 carboxyethyl chitosan exhibited improved antioxidant activity [81-83]. Chitooligosaccharides have also been chemically modified to improve their antioxidant activity, for instance by modification of the polymers with gallic acid $[84,85]$ or phenolic compounds [86].

Different methodologies have been used to determine chitosan and its derivatives antioxidant assays, which includes DPPH (2,2-diphenyl-1-picryl-hydrazyl-hydrate), ABTS (2,2-azinobis (3-ethylbenzothiazoline-6-sulphonic acid), and FRAP (ferric antioxidant power) assays, peroxide and hydroxyl radical scavenging assays or the use of macrophage models. DPPH and ABTS assays are based on electron and $\mathrm{H}$ atom transfer, while the FRAP assay is based on electron transfer reaction, as depicted in Figure 3. The ORAC (oxygen radical absorbance capacity assay) is also widely used to test antioxidant activities.

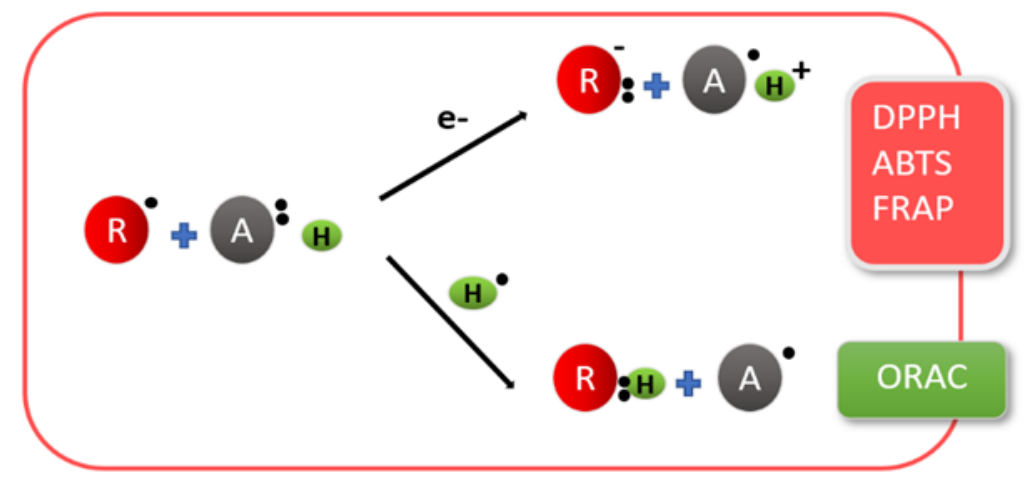

Figure 3. Methodologies used to determine antioxidant activities.

The disparity between the polymers tested and the methodologies used to test the activity produces considerable differences in the polymer concentrations that range from $50 \mu \mathrm{g} / \mathrm{mL}$ to $400 \mathrm{mg} / \mathrm{mL}$ [83]. Antioxidant activity is more remarkable for low molecular weight samples rather than for high molecular weight ones since shorter chains form fewer intramolecular hydrogen bonds and therefore the reactive groups are more accessible, contributing to the radical scavenging activity $[87,88]$. Regarding the effect of the acetylation degree, the antioxidant activity seems to decrease when this parametre increases [88].

\subsection{Anti-Inflammatory Properties}

The inflammatory process is an automatic physiological response of the body related to tissue damage. The main goal of the inflammatory response is to bring circulating leukocytes and plasma proteins to the site of the infection or tissue damage, to eliminate the causative agent, when possible, and to start the healing process. Although inflammation is necessary for survival, when it is very severe, unable to eradicate the causative agent, or is directed against the host, the inflammatory process may cause damage. The inflammatory process is strongly related to the generation of free radicals. Again, this activity seems to be more remarkable when the molecular weight of the chitosan is reduced and chitooligosaccharides exhibit higher activity.

After chitosan ( $300 \mathrm{kDa}$ ) depolymerization with cellulose, the activity of degraded polymers with medium molecular weight, low molecular weight and chitooligosaccharides $(156,72,7$ and $3.3 \mathrm{kDa})$ were tested in terms of NO secretion, cytokine production, and mitogen-activated protein kinase pathways in a model of lipopolysaccharide (LPS)-induced 
murine RAW 264.7 macrophages. Chitosan samples (parent, medium, and low) significantly inhibited NO production. On the contrary, the opposite effect was observed with the COS. The mechanism followed by the medium and low Mw chitosan to inhibited NF- $\kappa B$ activation and iNOS expression differed. For medium chitosan $(156 \mathrm{kDa})$ the process occurred via the binding to CR3 while for low molecular weight chitosan the process occurred via the binding to CR3 and TLR4 receptors. On the contrary, the lower molecular weight chitosans activated NF- $\mathrm{KB}$ and enhanced iNOS expression by binding to CD14, TLR4, and CR3 receptors to activate JNK signalling proteins [89]. In general, chitooligosaccharides are studied in more detail for this application compared to chitosan, due to their better solubility in aqueous media and better performance.

The effect of acetylation degree on the anti-inflammatory activities of COS has also been studied. Chitooligosaccharides with MW between 0.2 and $1.2 \mathrm{kDa}$ were enzymatically depolymerized, depending on the enzyme, fully deacetylated (fdCOS, mainly GlcN, $(\mathrm{GlcN}) 2,(\mathrm{GlcN}) 3$, and $(\mathrm{GlcN}) 4)$, partially acetylated (paCOS: a mixture of at least $11 \mathrm{Cos}$ with different proportions of GlcNAc and GlcN), and fully acetylated (faCOS, mainly GlcNAc, (GlcNAc)2 and (GlcNAc)3) were produced. The anti-inflammatory activity of the three COS mixtures was studied by measuring their ability to reduce the level of TNF- $\alpha$ in stimulated LPS murine macrophages (RAW 264.7). Only fdCOS and faCOS were able to significantly reduce this factor $[90,91]$. The inhibition of NO secretion by COSs revealed that $10 \%$ acetylated COS inhibited NO secretion significantly more than those with 50\% acetylation [92]. Citronellol grafted chitosan oligosaccharide derivatives have been produced to improve the anti-inflammatory activity of the oligosaccharides with degrees of substitution of $0.165,0.199$ and 0.182 , respectively. In all cases, the derivatives showed better performance than the parent COS. These derivatives reduced the expression levels of TNF- $\alpha$ by promoting the secretion of IL- 4 and IL- 10 and inactivated the NF- $\mathrm{KB}$ signalling pathway via inhibiting the phosphorylation of $\mathrm{p} 65, \operatorname{IKB} \alpha$, and $\operatorname{IKK} \beta$ [93].

Using the same chitosan as a starting material to produce chitooligosaccharides rendered samples with different anti-inflammatory behaviour. Chitooligosaccharides $(5-10 \mathrm{kDa}$, DD: $87 \%$ ) composed mainly of $42 \%$ fully deacetylated oligomers (A1-A3) plus $54 \%$ monoacetylated oligomers, produced by enzymatic degradation with chitosanase, attenuated the inflammation in lipopolysaccharide-induced mice and in RAW264.7 macrophages. On the contrary, chitooligosaccharides (5-10 kDa, DD: $89 \%$ ) from a two-step preparation (chemical degradation followed by enzymatic degradation with chitosanase) were composed of $50 \%$ fully deacetylated oligomers plus $27 \%$ monoacetylated oligomers (A1-A3) promoted the inflammatory response in both in vivo and in vitro models [94]. This result shows how small differences in the COS mixture have a strong effect on the mixture behaviour.

\section{Metallic Nanoparticles and Chitosan}

Metallic nanoparticles are usually defined as particles of metal atoms with sizes ranging between $1 \mathrm{~nm}$ to a few hundred nanometres [95]. These particles exhibit optical, chemical, and electronic properties that differ from individual atoms or bulk materials. These unique properties are highly appreciated for different applications such as catalysis, photonics, or biomedicine [96].

Metallic nanoparticles can be prepared using myriad physical or chemical methods. Metal ions can be reduced using chemicals $\left(\mathrm{NaBH}_{4}\right.$, vitamin $\mathrm{C}$ and others) $[97,98]$, plant extracts (due to their phenolic compounds) [99], using polymers such as chondroitin sulphate or heparin $[100,101]$, or using microorganisms containing specific enzymes such as nitrate reductase $[102,103]$. Other authors have proposed the use of sonochemical reduction [104], radiation [105], electrochemical reduction [106] or heat evaporation [107]. Once the formed metallic nanoparticles aggregate, the addition of stabilizers is needed [108] (Figure 4). 


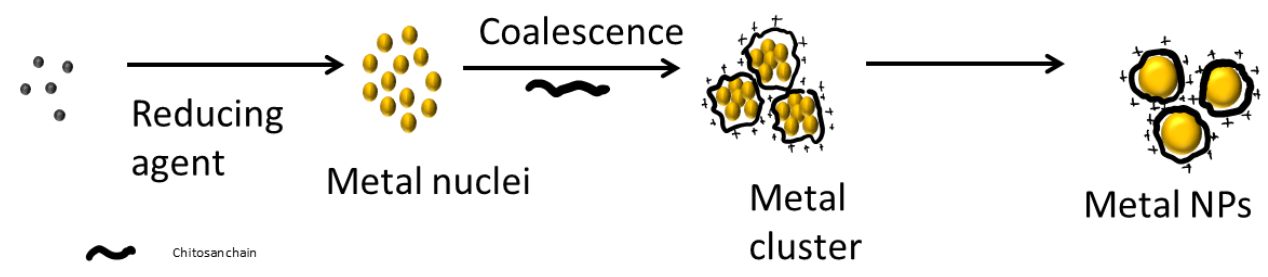

Figure 4. Scheme of metallic nanoparticle production and stabilization with chitosan.

The synthesis of metallic nanoparticles using chitosan as a reducing agent and/or stabilizing agent is well described. Some authors have also proposed that chitosan plays a role in the control of nanoparticle nucleation, thus controlling nanoparticle size to some extent since metal concentration also affects the nanoparticle size [97,109].

The reducing and stabilizing properties of chitosan seems to be related to the presence of $\mathrm{CH}_{2} \mathrm{OH}, \mathrm{CHO}$, and $\mathrm{NH}_{2}$ groups in the polymeric chain. Changes in the molecular weight or deacetylation degrees not only alter the number of these reactive groups but also modify the interactions (hydrogen bonds, electrostatic interactions, or steric interactions) present in the system.

In Table 4, some examples of the usage of chitosan in metallic nanoparticle synthesis are reviewed, including information about the molecules used as reducing agents, properties of the chitosan used when data are given, nanoparticle size, and morphology.

Table 4. Metallic nanoparticle based on chitosan.

\begin{tabular}{|c|c|c|c|c|c|}
\hline Metal & Reducing Agent & $\begin{array}{l}\text { Stabilizer } \\
\text { Chitosan } \\
\text { Mw and DD }\end{array}$ & NPs Size & Morphology & Ref. \\
\hline \multirow{8}{*}{ Palladium } & Ascorbic acid & Cs $180 \mathrm{kDa}, 75-85 \% \mathrm{DD}$ & $5-20$ & \multirow{7}{*}{$\begin{array}{c}\text { Spherical } \\
\text { Flower-spherical } \\
\text { Flower } \\
\text { Spherical } \\
\text { nd } \\
\text { Spherical } \\
\text { Spherical, large aggregate } \\
\text { (Pd:MeOH 10:1) }\end{array}$} & [98] \\
\hline & Ascorbic acid & Cs 50 to $190 \mathrm{kDa}, 75-85 \%$ & $50-70$ & & [110] \\
\hline & Ascorbic acid & Cs, 50 to $190 \mathrm{kDa}, 75-85 \%$ & $30-150$ & & [111] \\
\hline & Ascorbic acid & TMCs $20 \mathrm{kDa}$ & $55-120$ & & [112] \\
\hline & $\mathrm{NaBH}_{4}$ & Cs, $400 \mathrm{kDa}$ DD $100 \%$ & nd & & [109] \\
\hline & $\begin{array}{l}\mathrm{NaBH}_{4} \\
\mathrm{MeOH}\end{array}$ & $\begin{array}{l}\text { Cs, }(\sim 400 \mathrm{kDa}) \\
\mathrm{Cs},(\sim 400 \mathrm{kDa})\end{array}$ & $2-5$ & & {$[113]$} \\
\hline & $\mathrm{MeOH}$ & Cs, ( 400 KDa) & & & \\
\hline & $\begin{array}{l}\text { Hydrazine } \\
\mathrm{N}_{2} \mathrm{H}_{4}\end{array}$ & $\mathrm{Cs},(\sim 400 \mathrm{kDa})$ & $20 *$ & Highly aggregate & [113] \\
\hline \multirow{4}{*}{ Platinum } & $\mathrm{NaBH}_{4}$ & Cs, 400 kDa DD 100\% & $2-5$ & spherical & [109] \\
\hline & $\mathrm{NaBH}_{4}$ & $\mathrm{Cs},(\sim 400 \mathrm{kDa})$ & $2-3$ & spherical & [113] \\
\hline & $\mathrm{MeOH}$ & $\mathrm{Cs},(\sim 400 \mathrm{kDa})$ & 2 & spherical & [113] \\
\hline & $\begin{array}{l}\text { Hydrazine } \\
\mathrm{N}_{2} \mathrm{H}_{4}\end{array}$ & Cs, $(\sim 400 \mathrm{kDa})$ & $17-25 *$ & aggregates & [113] \\
\hline \multirow{7}{*}{ Gold } & $\mathrm{Cs}, 1278 \mathrm{kDa}$ & Cs, $1278 \mathrm{kDa}$ & 16 & \multirow{7}{*}{$\begin{array}{c}\text { Spherical } \\
\text { Spherical; polyhedral } \\
\text { Spherical } \\
\text { Spherical, triangles, polyhedral }\end{array}$} & [114] \\
\hline & Cs $817 \mathrm{KDa}$ & $\mathrm{Cs}, 817 \mathrm{KDa}$ & 5 & & [115] \\
\hline & $\mathrm{NaBH}_{4}$ & Cs, 400 kDa DD 100\% & & & \\
\hline & Cs DD $>85 \% ;>200,000 \mathrm{cps}$ & Cs, DD > $85 \% ;>200,000$ & 5-20 & & [101] \\
\hline & $\mathrm{NaBH}_{4}$ & Cs n.c. & $6-20$ & & [97] \\
\hline & $\cos 5 \mathrm{kDa}$ & $\cos 5 \mathrm{kDa}$ & $7-15$ & & [116] \\
\hline & Cs, & Cs, DD 53-95\%, Mw 2.6-490 kDa & $5-200 \mathrm{~nm}$ & & [117] \\
\hline \multirow{8}{*}{ Silver } & Cs & Cs $1240 \mathrm{kDa}, \mathrm{DA} 0.13$ & $10-150$ & \multirow{8}{*}{$\begin{array}{c}\text { Spherical } \\
\text { Triangles in long storage } \\
\text { Spherical } \\
\text { Spherical, fractal } \\
\text { Spherical } \\
\text { Spherical clusters } \\
\text { Spherical } \\
\text { Spherical }\end{array}$} & [118] \\
\hline & $\begin{array}{c}\mathrm{Cs} \\
\mathrm{Cs} \text { DD }>85 \% ;>200,000 \mathrm{cps}\end{array}$ & $\begin{array}{c}\text { Cs, high Mw, DA } 0.25 \\
\text { Cs DD }>85 \% ;>200,000 \mathrm{cps}\end{array}$ & $\stackrel{5}{20-200}$ & & {$[119]$} \\
\hline & Ascorbic acid & Cs $180 \mathrm{kDa}, 75-85 \% \mathrm{DD}$ & $5-20$ & & [98] \\
\hline & $\mathrm{NaBH}_{4}$ & Cs $400 \mathrm{kDa}$ DD $100 \%$ & $30-200$ & & [109] \\
\hline & Gamma radiation & Cs n.c. & $4-5$ & & [101] \\
\hline & Cs n.c. & Cs n.c. & $10-60$ & & [120] \\
\hline & Ascorbic acid/Cs $1278 \mathrm{kDa}$ & Cs $1278 \mathrm{kDa}$ & 8 & & [114] \\
\hline & $\begin{array}{l}\text { Cs n.c. } \\
\text { Cs }\end{array}$ & $\begin{array}{l}\text { Cs n.c. } \\
\text { Cs (50-190 kDaDD 75-85\%) }\end{array}$ & & & {$[121]$} \\
\hline
\end{tabular}

Cs: chitosan; TMCs: trimethyl chitosan; n.c.: non-characterized; nd: non-determined; ${ }^{*}$ aggregate size.

Data from Table 4 clearly show that the characteristics of the produced nanoparticles depend on the method used to produce the nanoparticles and the characteristics of the chitosan used to reduce and stabilize the metal ions. In general, due to the lack of a proper characterization of the chitosan samples and the variety of reaction conditions used it 
is very difficult to relate chitosan properties with the characteristics of the nanoparticles. Recently, the effect of chitosan Mw and acetylation degree on the preparation of AuNPs both as reducing and stabilizing agents has been analysed in detail [117]. The authors also took into consideration the effect of polymer and gold concentration, temperature, and reaction time. Their results showed that the chitosan acetylation degree and polymer concentration are the main parameters affecting the size and shape of the nanoparticles. Polymer molecular weight is related to the reductive efficiency since the reduction of the polymer size increases the amount of reducing sugars in the media. Our group has focused its research on the production of AgNPs using low molecular weight chitosan samples. As previously described in this review, the characteristics of these low molecular weight chitosan samples depend on the enzyme used to produce the samples. We hypothesised that samples with similar $\mathrm{Mw}$ and acetylation degrees may exhibit different behaviour due to the monomer pattern. Our results showed that pattern is a key parameter in the stabilization of the AgNPs, corroborating this hypothesis [123] A chitosan sample (538 kDa, DD 52\%) with little ability to stabilize AgNPs was depolymerized with lysozyme (fraction $\mathrm{L}$ ) and chitosanase (fraction $\mathrm{Q}$ ) and the resulting reaction mixture was separated into three fractions by tangential ultrafiltration (fraction $\mathrm{F} 1(\mathrm{Mw}>30 \mathrm{kDa})$, fraction F2 (Mw 30-10 kDa), and fraction F3 (Mw 10-5 kDa). After depolymerization, an increase in the DD was observed with values between $62-74 \%$ ). All fractions were able to reduce the silver ion, but relevant differences were observed in terms of stabilization (Figure 5). AgNPs produced with chitosan samples depolymerized with chitosanase (FQ2 and FQ3) were larger, poorly stabilized, and tended to form large aggregates visible with the naked eye. On the contrary, AgNPs produced with chitosan depolymerized with lysozyme were smaller and more stable in all cases. As the $\mathrm{Mw}$ of the fraction was reduced, the polydispersity was also lowered. After one month, the stability of the AgNPs was evaluated and results showed that AgNPs produced with the fractions F1Q and F1L were the most appropriate for nanoparticle stabilization.

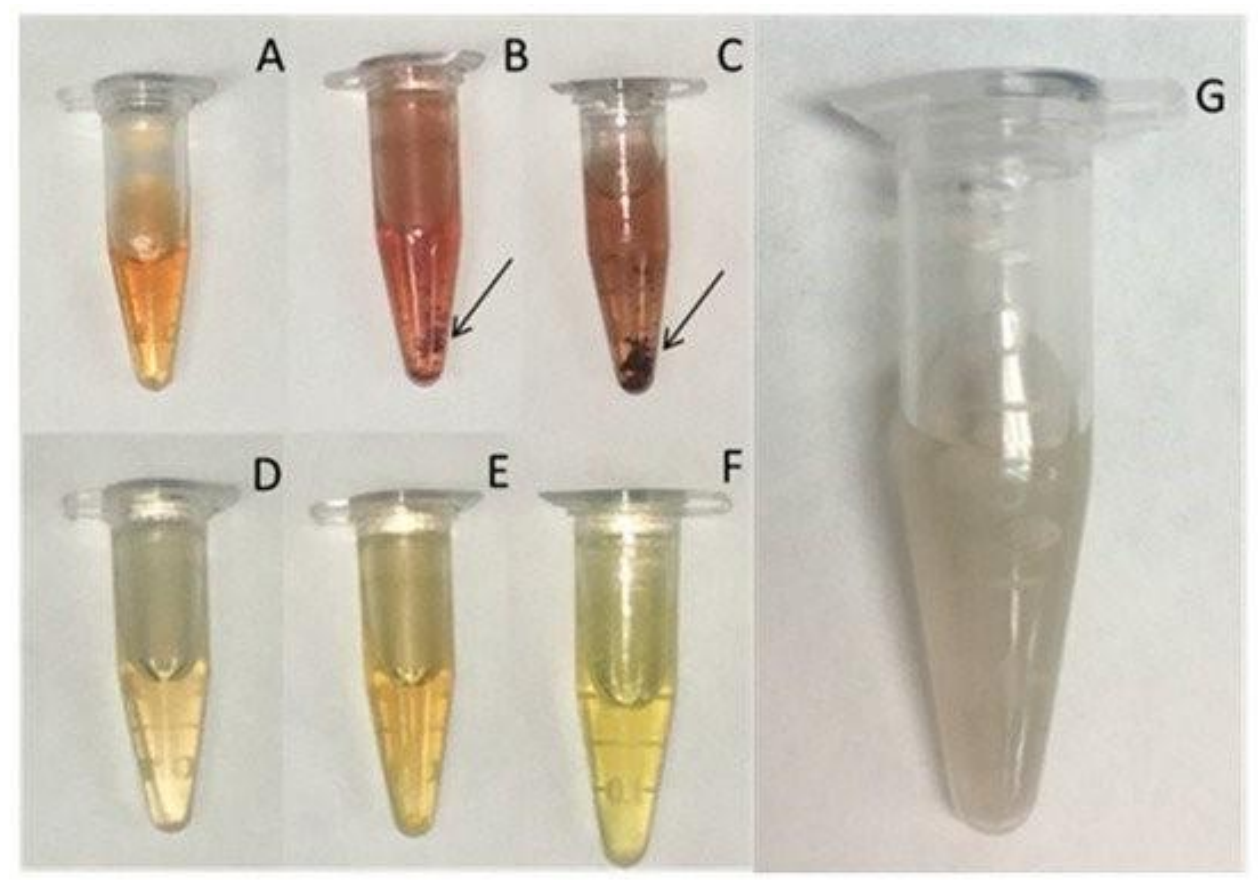

Figure 5. Visual evaluation of AgNP-polymer solutions after 5 h at $90{ }^{\circ}$ C. (A) F1Q, (B) F2Q, (C) F3Q, (D) F1L, (E) F2L, (F) F3L, and (G) parent chitosan. Arrows indicate the presence of aggregates. (C) 2021 by the authors. Licensee MDPI, Basel, Switzerland (CC BY) license [123].

The AgNPs produced with lysozyme fractions and the higher Mw fraction of chitosanase were tested in the catalytic reduction of TBO [124]. AgNPs produced through 
chitosan depolymerization with lysozyme showed better performance than the sample produced using chitosanase. Moreover, AgNPs produced with fraction F1L exhibited the best performance in the reaction. That is, the effect of the polymer pattern goes further than affecting optical properties and stability and differences in the catalytical behaviour was also observed. This difference is not due to the polymer, since control reactions showed that the polymeric fractions were not able to catalyse the reduction in TBO and therefore the effect is solely ascribed to the AgNPs.

\section{Chitosan in Biocatalysis}

The use of immobilized enzymes for catalysing chemo-, regio- and/or stereoselective chemical reactions is a very useful and well-known technique [125-142]. In this sense, the use of chitosan for immobilizing enzymes, either as a carrier for covalent linking or as an encapsulation vehicle, is well reported [143-149]. Our group described the production of enantiopure D-p-hydroxyphenylglycine (D-p-HPG, Figure 6) using a multi-enzyme system containing D-hydantoinase and D-carbamoylase encapsulated in chitosan-based materials [150-153].

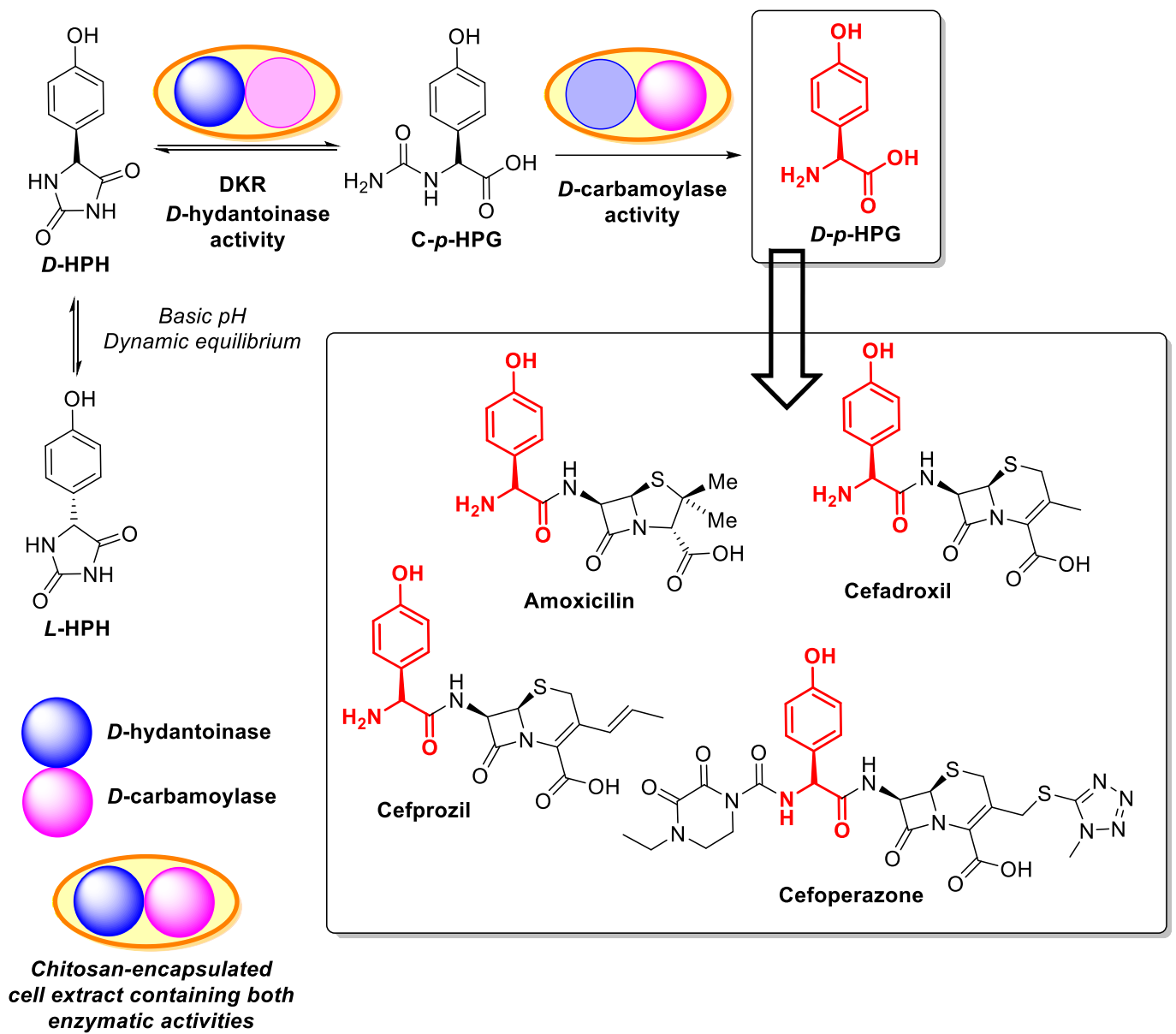

Figure 6. Schematic representation of the production of $p$-hydroxyphenylglycine (p-HPG) starting from a racemic mixture of $p$-hydroxyphenyl hydantoin (HPH) using a multi-enzyme system containing immobilized $D$-hydantoinase and $D$-carbamoylase.

$D-p$-HPG (or simply D-HPG, a D-amino acid) is a very useful chiral synthon, mainly used for the preparation of different semi-synthetic antibiotics, such as amoxicillin, cefadroxil, cefprozil, or cefoperazone [154-156] (Figure 6), but also anticancer drugs [157] and some heterocyclic compounds [158-161]. 
For preparing D-HPG, one of the most efficient processes is the so-called "hydantoinase process", depicted in Figure 6. This cascade of enzymatic reactions, aiming to produce optically pure amino acids [162,163], requires an initial step catalyzed by a Dspecific hydantoinase [E.C. 3.5.2.2.] to transform D-p-hydroxyphenyl hydantoin (D-HPH) into N-carbamoyl-D-p-hydroxyphenylglycine (C-p-HPG), which should be subsequently hydrolyzed by a second enzyme, a highly enantiospecific $\mathrm{N}$-carbamoyl amino acid amidohydrolase (also termed D-carbamoylase; E.C.3.5.1.77), to furnish the free amino acid. One of the main features of the hydantoinase process derives from the spontaneous racemization of $\mathrm{D}-\mathrm{HPH}$ at $\mathrm{pH}$ values higher than $\mathrm{pH} 8$, caused by the acidic hydrogen at position 5 of the imidazolidine-2,4-dione ring, which allows for oxo-enol-tautomerism. This leads to a dynamic-kinetic resolution (DKR), allowing for the use of a mixture of L-and D-HPH as the initial substrate and a theoretical $100 \%$ conversion and $100 \%$ optically pure D-amino acid production (Figure 6).

Both enzymes have been reported to be present in different microorganisms, such as Agrobacterium sp., Pseudomonas sp., Arthrobacter crystallopoites, or Sinorhizobium morelense [151], and can be used either as whole cells, crude cell extracts, or purified enzymes (see Aranaz et al. [151] and references therein). If using isolated enzymes, immobilization is an excellent strategy for stabilizing the enzymatic cocktail due to the fact that D-hydantoinases are quite stable but D-carbamoylases display low thermostability and are prone to suffer oxidative degradations. In this sense, different protocols have been described (see Aranaz et al. [151] and references therein), and our group described how a multi-enzyme extract from Agrobacterium radiobacter rich in D-hydantoinase and $\mathrm{N}$-carbamoyl-D-amino acid amidohydrolase was easily immobilized via adsorption on chitin and chitosan for its application in the synthesis of p-hydroxyphenylglycine [153]. In fact, this adsorption derivative on chitin showed higher activity compared to the covalent one, and much greater $\mathrm{pH}$ stability compared to the soluble multi-enzymatic extract; on the other hand, the adsorption derivative exhibited greater $\mathrm{pH}$-stability in the $\mathrm{pH}$ range under study, showing higher activity at low temperatures. Anyhow, as the immobilized derivatives could not be properly reused, we developed a new strategy based on the encapsulation of a crude cell extract from the same microorganism, containing both enzymes, in alginate beads [164]. This biocatalyst could be reused six times in the presence of solid HPH particles in a stirred batch reactor without losing any activity until the beads started to burst. Anyhow, as these alginate-based catalysts showed low stability in calcium chelating buffers (i.e. phosphate buffers) and easy microbial contamination during storage at $4{ }^{\circ} \mathrm{C}$, another immobilization matrix, alginate-chitosan polyelectrolyte complexes, was assessed [150,152]. Thus, alginate mixed chitosan capsules were prepared in one step (by simply dropping an alginate solution containing the extract into a chitosan solution containing calcium ions) or in a two-step process (preformed calcium-alginate capsules loaded with the crude cell extract were subsequently coated with chitosan). The encapsulation yields were around $60 \%$ and independent of the characteristics of the different chitosans used. However, $\mathrm{p}-\mathrm{HPG}$ production was indeed affected by chitosan acylation degree D-D (the lower D-D, the lower p-HPG) but not by chitosan molecular weight. Generally speaking, the best biocatalyst allowed for a p-HPG production yield of around $60 \%$ without any significant protein release to the reaction media. Interestingly, this encapsulation procedure improved the stability of D-carbamoylase against oxidative damage during storage, particularly after freeze-drying. In addition, the alginate coated chitosan capsules could be reused eight times without enzymatic activity loss before D-carbamoylase started losing its activity and alginate-chitosan beads suffered burst problems contaminating the reaction.

In a collaboration with the group of Dr. Fernández-Lucas, we described the covalent immobilization of a recombinant nucleoside 2'-deoxyribosyltransferase from Lactobacillus reuteri (LrNDT) on cross-linked magnetic chitosan beads via epichlorohydrin activation under alkaline conditions, and subsequent incubation with glutaraldehyde [165], as schematized in Figure 7. 


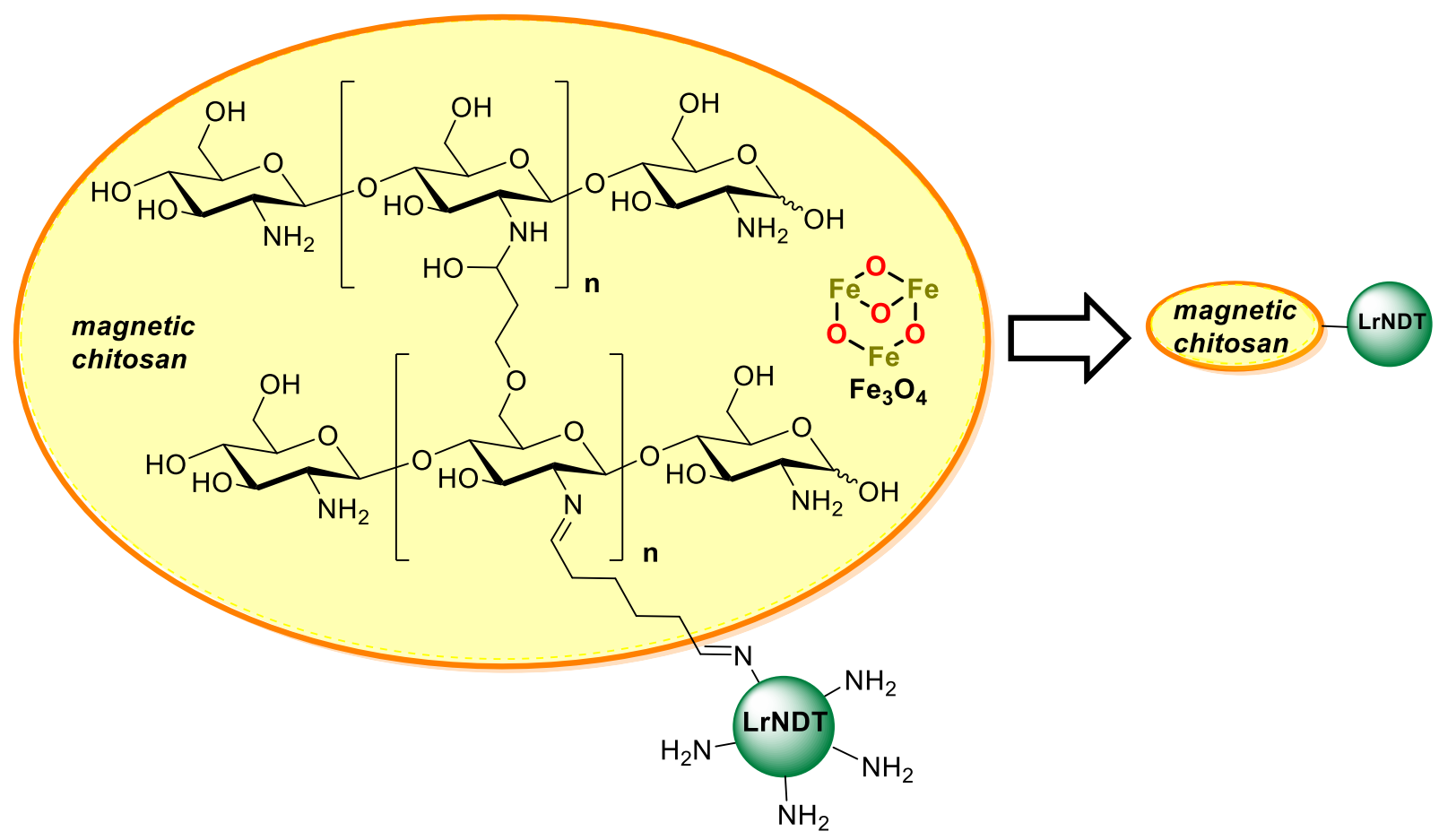

Figure 7. Schematic representation of the immobilization of a recombinant nucleoside $2^{\prime}$-deoxyribosyltransferase from Lactobacillus reuteri (LrNDT) on cross-linked magnetic chitosan beads. Adapted from Fernández-Lucas et al. [165].

Hence, by varying the amount of magnetite $\left(\mathrm{Fe}_{3} \mathrm{O} 4\right)$ and epichlorohydrin (EPI), different macroscopic beads were prepared and fully characterized (by scanning electron microscopy, spin electron resonance (ESR), and vibrating sample magnetometry (VSM)) before being used as supports. Once activated with glutaraldehyde, the best support was chosen after assessment of immobilization yield and product yield using as a standard reaction for the synthesis of thymidine (dThd) from 2'-deoxyuridine (dUrd) and thymine (Thy), as depicted in Figure 7. Additionally, optimal conditions for chitooligosaccharides with the highest activity of immobilized LrNDT on magnetic chitosan were carried out using response surface methodology (RSM). Thus, the best-immobilized biocatalyst retained 50\% of its maximal activity after $56.3 \mathrm{~h}$ at $60{ }^{\circ} \mathrm{C}$ and no lost activity was observed after storage at $40{ }^{\circ} \mathrm{C}$ for $144 \mathrm{~h}$. Subsequently, this innovative immobilized biocatalyst was employed in the enzymatic synthesis of 2'-deoxyribonucleoside analogues and arabinosyl nucleosides such as vidarabine (ara-A) and cytarabine (ara-C), as depicted in Figure 8, leading to moderate or good yields at $2 \mathrm{~h}$ reaction time. Remarkably, the immobilized derivatives could be easily recovered and recycled for 30 consecutive batch reactions without any significant decrease in the catalytic activity in the synthesis of 2,6-diaminopurine-2'-deoxyriboside (2,6-DAPdRib) and 5-trifluorothymidine (5-tFThd). 

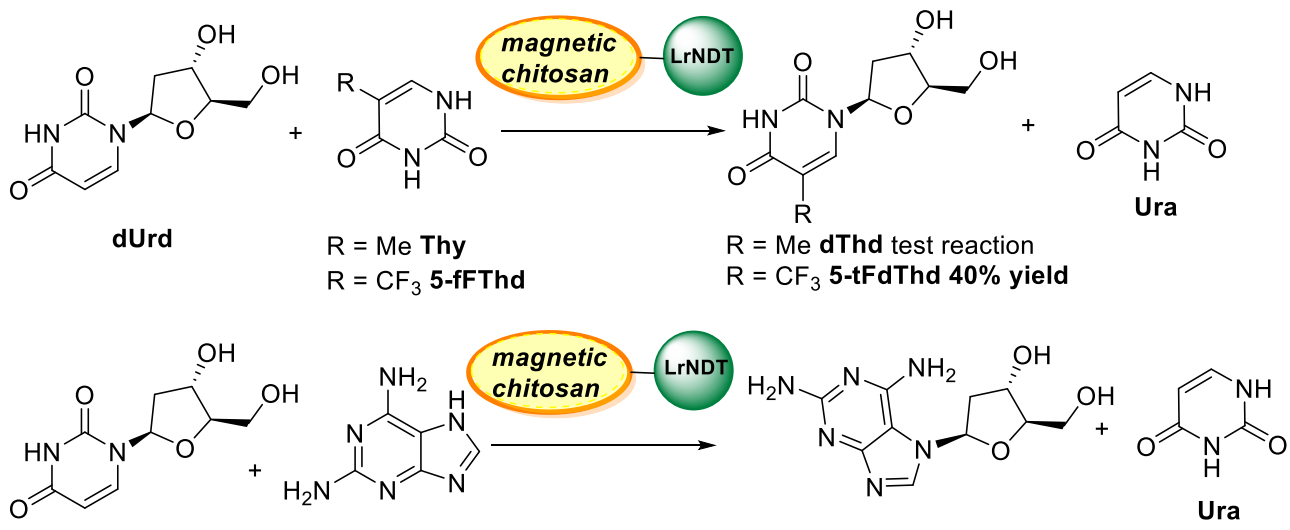

dUrd

2,6-DAP

2,6-DAPdRib $83 \%$ yield<smiles>O=c1ccn([C@@H]2OC(CO)[C@@H](O)[C@H]2F)c(=O)[nH]1</smiles>

2'-FdUrd<smiles>Nc1ncnc2nc[nH]c12</smiles>

Ade
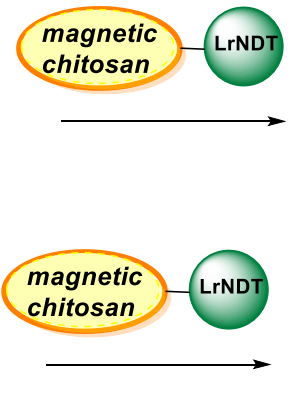

yyt<smiles>Nc1cc[nH]c(=O)n1</smiles>

magnetic itosan<smiles>Nc1ncnc2ncn(C3OC(C[OH2+])[C@@H](O)[C@H]3F)c12</smiles>

2'-FdAde $10 \%$ yield<smiles>Nc1ccn([C@@H]2OC(CO)[C@@H](O)C2F)c(=O)n1</smiles>

2'-FdCyd $67 \%$ yield<smiles>O=c1cc[nH]c(=O)[nH]1</smiles>

Ura<smiles>O=c1ccn([C@@H]2O[C@H](CO)[C@@H](O)[C@H]2F)c(=O)[nH]1</smiles><smiles>O=c1ccn([C@@H]2O[C@H](CO)[C@@H](O)[C@H]2O)c(=O)[nH]1</smiles>

Ara-U

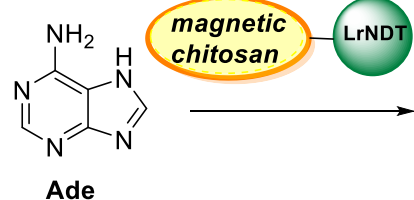

Ade<smiles>O=c1ccn([C@@H]2OC(CO)[C@@H](O)[C@H]2O)c(=O)[nH]1</smiles>

Ara-U<smiles>Nc1cc[nH]c(=O)n1</smiles>

Cyt

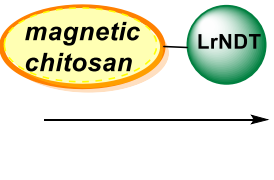

magnetic

hitosan<smiles>Nc1ncnc2ncn(C3O[C@H](CO)[C@@H](O)[C@H]3O)c12</smiles>

Ara-A $14 \%$ yield<smiles>O=c1cc[nH]c(=O)[nH]1</smiles>

Ura

Figure 8. Synthesis of different natural and non-natural nucleosides using a recombinant nucleoside 2'deoxyribosyltransferase from Lactobacillus reuteri (LrNDT) immobilized on cross-linked magnetic chitosan beads [165]. Commission on Biochemical Nomenclature: adenine (Ade), uracil (Ura), cytosine (Cyt), thymine (Thy), 2,6-diaminopurine (2,6-DAP), 5-trifluorothymine (5-tFThy), 2'-deoxyuridine (dUrd), 2'-deoxyadenosine (dAdo), 2'-deoxycytidine (dCyd), thymidine (dThd), 2,6-diaminopurine-2'-deoxyriboside (2,6-DAPdRib), 5-trifluorothymidine (5-tFdThd), 2'-fluoro-20deoxyuridine (2'-FdUrd), 2'-fluoro-2'-deoxycitydine (2'-FdCyd), ara-uracil (ara-U), ara-adenine (ara-A).

\section{Chitosan in Drug Delivery}

Since the introduction of the first polymers in drug delivery, chitosan has shown superior biological and physiochemical properties for a wide variety of biomedical and industrial applications. The main feature of this biopolymer is its cationic character due to amino groups. These amino groups are also responsible for properties such as controlled drug release, mucoadhesion, in situ gelation, transfection, permeation enhancement, and efflux pump inhibitory properties [166]. Moreover, interest in this biomaterial due to its 
central nervous system (CNS) bio-medical implementation has increased because of its ability to cross the blood brain barrier (BBB) [167].

Therefore, chitosan is widely used in drug delivery due to its technological properties, which allow us to process the polymer in different ways (Table 5).

Table 5. Some examples of chitosan presentations in drug delivery.

\begin{tabular}{cc}
\hline Presentation & References \\
\hline Films & {$[168-171]$} \\
Sponges & {$[172,173]$} \\
Scaffolds & {$[174,175]$} \\
Nanoparticles & {$[176]$} \\
Microspheres & {$[177-179]$} \\
Hydrogels & {$[180-182]$} \\
Aerogels & {$[183-185]$} \\
Fibers & {$[186,187]$} \\
Microneedles & {$[188,189]$} \\
Coated Liposomes & {$[190,191]$} \\
Nanocomposites & {$[192,193]$} \\
Composites & {$[194]$} \\
\hline
\end{tabular}

Initially, a chitosan salt (chitosan hydrochloride) was approved in 2002 by the Pharmacopeia. Chitosan was first introduced as an excipient into the European Pharmacopeia 6.0 and the 29th edition of the United States Pharmacopeia (USP) 34-NF almost ten years later. These monographs contain the assays and establish limits to be observed when the polymer is used as a pharmaceutical excipient $[195,196]$. The increase in the number of publications regarding the use of this polymer in drug delivery is shown in Figure 9 and reveals a strong increase since 2002 that is still maintained today.

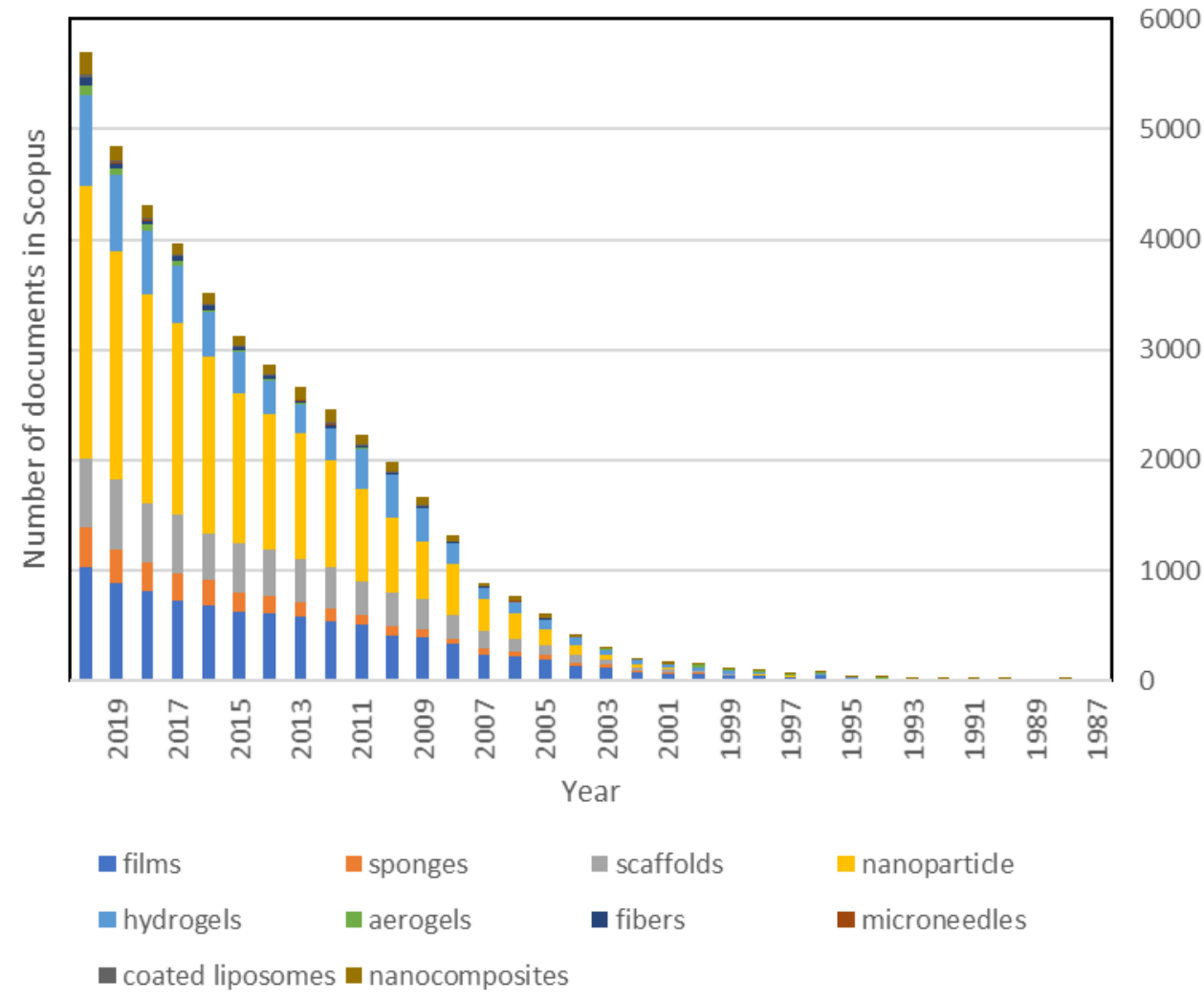

Figure 9. Publications about chitosan drug delivery in Scopus (1987-2020). 
Chitosan films are easily produced by solvent-casting methodologies, but more complex systems can be produced by blending the polymer with others such as pectin [197] or by producing layer-by-layer films with negatively charged polymers like polyacid [198], poly (lactic-co-glycolic acid) [199] or polylactic [200], among others. Besides their safety, biocompatibility, and biodegradability, biopolymer-based films have been drawing increasing interest as excellent candidates not only as controlled-drug delivery systems but also as materials to produce contact lenses, wound dressings, and tissue engineering matrices.

Particulate chitosan-based systems (micro and nano systems) are widely used for the encapsulation of a large variety of molecules such as growth factors [178], antimicrobials [201], painkillers [202], anti-tumoral [203] or anti-inflammatory drugs [204].

Recently, chitosan has been used for the fabrication of microneedles (MNs) due to its film-forming ability, biodegradability, and biocompatibility, making it suitable for topical and transdermal drug delivery [188]. In particular, the use of chitosan MNs in vaccination is a hot topic of discussion [205-207]. The use of chitosan MNs in wound healing and point-of-care testing is revolutionary and gives hope of more useful developments in these areas. However, some drawbacks still need further investigation. The development of MNs devices with adequate mechanical strength to penetrate the skin without causing pain and skin damage and the development of efficient methods for their sterilization remain challenging [208].

A comparison of the number of publications containing "Chitosan + drug delivery" in Scopus and patents in Lens portal (free, open patent, and scholarly search) is shown in Figure 10. As observed, the number of patents is almost four times the number of publications, showing the increasing application of this polymer in the drug delivery field. An interesting article by Kurakula and Raghavendra summarizes the chitosan biomedical trends and the related patents [209].

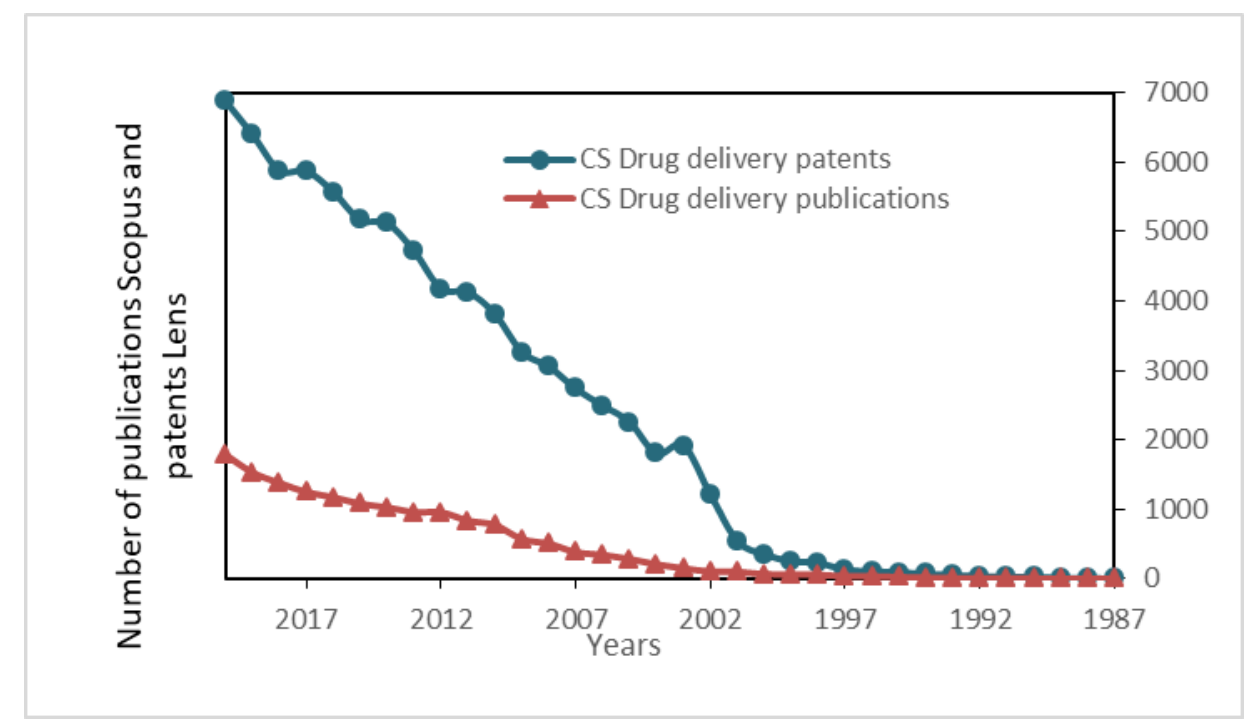

Figure 10. Publications about chitosan drug delivery in Scopus and patents in Lens (1987-2020).

\section{Conclusions and Prognosis}

Chitosan and its derivatives have been used in a myriad of applications for a long time. The potential interest of these polymers is clear when observing the number of articles and patents that appear every year and the growing market perspective. In some of these applications such as agriculture or the food industry, the use of chitosan in the market is well established. The use of chitosan has extended to a large number of research areas from Materials Science to Arts and the Humanities (Figure 11). 


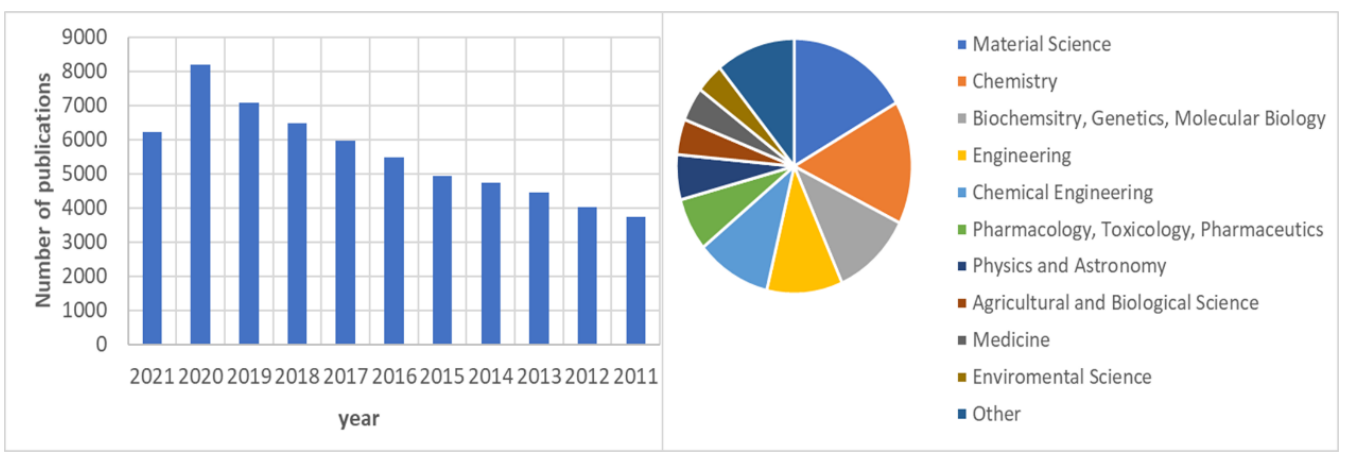

Figure 11. Number of publications and distribution by area in the period 2011-2021. Search of chitosan word in Scopus (abstract, title, keywords).

However, chitosan potentiality is somehow hindered by the inconsistency in the research data and the lack of knowledge in the ultimate mechanism underlying the properties of chitosan. Between 2011-2020, the number of publications on chitosan has displayed a steady growth. In 2021, a drop is observed, which is ascribed in part to the large number of reviews published in 2020, probably due to the COVID-19 pandemic, which has affected normal laboratory work worldwide. Regardless, we consider that this growth will continue in the following years, driven by the strong effort that has been carried out by the Chitin Science Scientific Community in the systematic research on this polymer. In fact, its approval by different agencies has boosted the interest in this polymer both by the industrial and scientific communities.

Chitosan specifications are ultimately related to its final application. Thus, high quality chitosans with low heavy metal and low endotoxin contents are required for biomedical and pharmaceutical uses. Moreover, strict control of production is needed to avoid uncontrollable hydrolysis and chemical modifications during polymer isolation. Therefore, chitosan production is not a trivial issue. To date, chitosan production cannot be considered fully sustainable due to the large amount of acid and basic reagents needed and the high temperatures required. Unfortunately, biotechnological processes using biocatalysts are currently limited to the laboratory scale so that implementation of these greener processes at a large scale is certainly one of the milestones we want to see being achieved in the next decade.

Author Contributions: Conceptualization: I.A. and N.A.; writing-original draft preparation, I.A., A.R.A., N.A., M.C.C. and C.A.; writing-review and editing, I.A., A.R.A., N.A., M.C.C., C.A. and B.E.; funding acquisition, A.H.C., N.A. and A.R.A. All authors have read and agreed to the published version of the manuscript.

Funding: This research was funded by Spanish Ministry of Science and Innovation (PID2019105337RB-C22) and Banco de Santander-Complutense Research Projects (PR87/19-22676).

Institutional Review Board Statement: Not applicable.

Informed Consent Statement: Not applicable.

Data Availability Statement: Not applicable.

Conflicts of Interest: The authors declare no conflict of interest.

\section{References}

1. Ghormade, V.; Pathan, E.K.; Deshpande, M.V. Can fungi compete with marine sources for chitosan production? Int. J. Biol. Macromol. 2017, 104, 1415-1421. [CrossRef]

2. Aranaz, I.; Mengíbar, M.; Harris, R.; Paños, I.; Miralles, B.; Acosta, N.; Galed, G.; Heras, A. Functional characterization of chitin and chitosan. Curr. Chem. Biol. 2009, 3, 203-230.

3. Rinaudo, M. Chitin and chitosan: Properties and applications. Prog. Polym. Sci. 2006, 31, 603-632. [CrossRef] 
4. Jiang, Y.; Fu, C.; Wu, S.; Liu, G.; Guo, J.; Su, Z. Determination of the deacetylation degree of chitooligosaccharides. Mar. Drugs 2017, 15, 332. [CrossRef]

5. Ways, T.M.M.; Lau, W.M.; Khutoryanskiy, V.V. Chitosan and its derivatives for application in mucoadhesive drug delivery systems. Polymers 2018, 10, 267. [CrossRef] [PubMed]

6. Sizílio, R.H.; Galvão, J.G.; Trindade, G.G.G.; Pina, L.T.S.; Andrade, L.N.; Gonsalves, J.K.M.C.; Lira, A.A.M.; Chaud, M.V.; Alves, T.F.R.; Arguelho, M.L.P.M.; et al. Chitosan/pvp-based mucoadhesive membranes as a promising delivery system of betamethasone-17-valerate for aphthous stomatitis. Carbohydr. Polym. 2018, 190, 339-345. [CrossRef] [PubMed]

7. Azuma, K.; Osaki, T.; Minami, S.; Okamoto, Y. Anticancer and Anti-Inflammatory Properties of Chitin and Chitosan Oligosaccharides. J. Funct. Biomater. 2015, 6, 33-49. [CrossRef] [PubMed]

8. Avelelas, F.; Horta, A.; Pinto, L.F.V.; Marques, S.C.; Nunes, P.M.; Pedrosa, R.; Leandro, S.M. Antifungal and antioxidant properties of chitosan polymers obtained from nontraditional Polybius henslowii sources. Mar. Drugs 2019, 17, 239. [CrossRef]

9. Ke, C.L.; Deng, F.S.; Chuang, C.Y.; Lin, C.H. Antimicrobial actions and applications of Chitosan. Polymers 2021, 13, 904. [CrossRef]

10. Shih, P.Y.; Liao, Y.T.; Tseng, Y.K.; Deng, F.S.; Lin, C.H. A potential antifungal effect of chitosan against candida albicansis mediated via the inhibition of SAGA complex component expression and the subsequent alteration of cell surface integrity. Front. Microbiol. 2019, 10, 602. [CrossRef]

11. Sarkar, S.; Das, D.; Dutta, P.; Kalita, J.; Wann, S.B.; Manna, P. Chitosan: A promising therapeutic agent and effective drug delivery system in managing diabetes mellitus. Carbohydr. Polym. 2020, 247, 116594. [CrossRef]

12. Amirani, E.; Hallajzadeh, J.; Asemi, Z.; Mansournia, M.A.; Yousefi, B. Effects of chitosan and oligochitosans on the phosphatidylinositol 3-kinase-AKT pathway in cancer therapy. Int. J. Biol. Macromol. 2020, 164, 456-467. [CrossRef] [PubMed]

13. Ueno, H.; Mori, T.; Fujinaga, T. Topical formulations and wound healing applications of chitosan. Adv. Drug Deliv. Rev. 2001, 52, 105-115. [CrossRef]

14. Chitosan Market Size, Share E Trends Analysis Report by Application (Pharmaceutical E Biomedical, Water Treatment, Cosmetics, Food E Beverage), By Region (APAC, North America, Europe, MEA), and Segment Forecasts, 2020-2027); Report ID: 978-1-68038-798-8; Grand View Research: San Francisco, CA, USA, 2020. Available online: https:/ /www.grandviewresearch.com/industry-analysis/ global-chitosan-market (accessed on 31 August 2020).

15. Kaczmarek, M.B.; Struszczyk-Swita, K.; Li, X.; Szczęsna-Antczak, M.; Daroch, M. Enzymatic modifications of chitin, chitosan, and chitooligosaccharides. Front. Bioeng. Biotechnol. 2019, 7, 243. [CrossRef]

16. Domard, A. $\mathrm{pH}$ and c.d. measurements on a fully deacetylated chitosan: Application to CuII-polymer interactions. Int. J. Biol. Macromol. 1987, 9, 98-104. [CrossRef]

17. Rinaudo, M.; Pavlov, G.; Desbrières, J. Solubilization of Chitosan in Strong Acid Medium. Int. J. Polym. Anal. Charact. 1999, 5, 267-276. [CrossRef]

18. Cho, Y.W.; Jang, J.; Park, C.R.; Ko, S.W. Preparation and solubility in acid and water of partially deacetylated chitins. Biomacromolecules 2000, 1, 609-614. [CrossRef]

19. Sogias, I.A.; Khutoryanskiy, V.V.; Williams, A.C. Exploring the factors affecting the solubility of chitosan in water. Macromol. Chem. Phys. 2010, 211, 426-433. [CrossRef]

20. Kasaai, M.R.; Arul, J.; Charlet, G. Intrinsic viscosity-molecular weight relationship for chitosan. J. Polym. Sci. Part B 2000, 38, 2591-2598. [CrossRef]

21. Chattopadhyay, D.P.; Inamdar, M.S. Aqueous behaviour of chitosan. Int. J. Polym. Sci. 2010, 2010, 1-7. [CrossRef]

22. Wang, W.; Xu, D. Viscosity and flow properties of concentrated solutions of chitosan with different degrees of deacetylation. Int. J. Biol. Macromol. 1994, 16, 149-152. [CrossRef]

23. Aranaz, I.; Harris, R.; Heras, A. Chitosan amphiphilic derivatives. Chemistry and applications. Curr. Org. Chem. 2010, 14, 308-330. [CrossRef]

24. Ding, K.; Wang, Y.; Wang, H.; Yuan, L.; Tan, M.; Shi, X.; Lyu, Z.; Liu, Y.; Chen, H. 6-O-sulfated chitosan promoting the neural differentiation of mouse embryonic stem cells. ACS Appl. Mater. Interfaces 2014, 6, 20043-20050. [CrossRef]

25. Coquery, C.; Negrell, C.; Caussé, N.; Pébère, N.; David, G. Synthesis of new high molecular weight phosphorylated chitosans for improving corrosion protection. Pure Appl. Chem. 2019, 91, 509-521. [CrossRef]

26. Heras, A.; Rodríguez, N.M.; Ramos, V.M.; Agulló, E. N-methylene phosphonic chitosan: A novel soluble derivative. Carbohydr. Polym. 2001, 44, 1-8. [CrossRef]

27. Ramos, V.M.; Rodríguez, N.M.; Rodríguez, M.S.; Heras, A.; Agulló, E. Modified chitosan carrying phosphonic and alkyl groups. Carbohydr. Polym. 2003, 51, 425-429. [CrossRef]

28. Jayakumar, R.; Reis, R.L.; Mano, J.F. Synthesis and characterization of N-methylenephenyl phosphonic chitosan. J. Macromol. Sci. Part A Pure Appl. Chem. 2007, 44, 271-275. [CrossRef]

29. Ramos, V.M.; Rodríguez, M.S.; Agulló, E.; Rodríguez, N.M.; Heras, A. Chitosan with phosphonic and carboxylic group: New multidentate ligands. Int. J. Polym. Mater. 2002, 51, 711-720. [CrossRef]

30. Ramos, V.M.; Rodríguez, N.M.; Díaz, M.F.; Rodríguez, M.S.; Heras, A.; Agulló, E. N-methylene phosphonic chitosan. Effect of preparation methods on its properties. Carbohydr. Polym. 2003, 52, 39-46. [CrossRef]

31. Zhu, D.; Yao, K.; Bo, J.; Zhang, H.; Liu, L.; Dong, X.; Song, L.; Leng, X. Hydrophilic/lipophilic N-methylene phosphonic chitosan as a promising non-viral vector for gene delivery. J. Mater. Sci. Mater. Med. 2010, 21, 223-229. [CrossRef] [PubMed] 
32. Kasaai, M.R.; Arul, J.; Charlet, G. Fragmentation of chitosan by ultrasonic irradiation. Ultrason. Sonochem. 2008, 15, 1001-1008. [CrossRef]

33. Wu, T.; Zivanovic, S.; Hayes, D.G.; Weiss, J. Efficient reduction of chitosan molecular weight by high-intensity ultrasound: Underlying mechanism and effect of process parameters. J. Agric. Food Chem. 2008, 56, 5112-5119. [CrossRef]

34. Chang, K.L.B.; Tai, M.C.; Cheng, F.H. Kinetics and products of the degradation of chitosan by hydrogen peroxide. J. Agric. Food Chem. 2001, 49, 4845-4851. [CrossRef]

35. Vårum, K.M.; Holme, H.K.; Izume, M.; Stokke, B.T.; Smidsrød, O. Determination of enzymatic hydrolysis specificity of partially N-acetylated chitosans. Biochim. Biophys. Acta Gen. Subj. 1996, 1291, 5-15. [CrossRef]

36. Skjak-Braek, G.; Anthonsen, T.; Sandford, P. (Eds.) Chitin and Chitosan: Sources, Chemistry, Biochemistry, Physical Properties and Applications; Elsevier Applied Science: London, UK, 1989.

37. Varum, K.M.; Ottoy, M.H.; Smidsrod, O. Acid hydrolysis of chitosans. Carbohydr. Polym. 2001, 46, 89-98. [CrossRef]

38. Cabrera, J.C.; Van Cutsem, P. Preparation of chitooligosaccharides with degree of polymerization higher than 6 by acid or enzymatic degradation of chitosan. Biochem. Eng. J. 2005, 25, 165-172. [CrossRef]

39. Thadathil, N.; Velappan, S.P. Recent developments in chitosanase research and its biotechnological applications: A review. Food Chem. 2014, 150, 392-399. [CrossRef]

40. Aam, B.B.; Heggset, E.B.; Norberg, A.L.; Sørlie, M.; Vårum, K.M.; Eijsink, V.G.H. Production of chitooligosaccharides and their potential applications in medicine. Mar. Drugs 2010, 8, 1482-1517. [CrossRef] [PubMed]

41. Kumar, A.B.V.; Tharanathan, R.N. A comparative study on depolymerization of chitosan by proteolytic enzymes. Carbohydr. Polym. 2004, 58, 275-283.

42. Li, J.; Du, Y.; Yang, J.; Feng, T.; Li, A.; Chen, P. Preparation and characterisation of low molecular weight chitosan and chitooligomers by a commercial enzyme. Polym. Degrad. Stab. 2005, 87, 441-448. [CrossRef]

43. Li, J.; Du, Y.; Liang, H. Influence of molecular parameters on the degradation of chitosan by a commercial enzyme. Polym. Degrad. Stab. 2007, 92, 515-524. [CrossRef]

44. Qin, C.; Du, Y.; Zong, L.; Zeng, F.; Liu, Y.; Zhou, B. Effect of hemicellulase on the molecular weight and structure of chitosan. Polym. Degrad. Stab. 2003, 80, 435-441. [CrossRef]

45. Lund, K.E.; Nielsen, H.H. Proteolysis in salmon (Salmo salar) during cold storage; effects of storage time and smoking process. J. Food Biochem. 2001, 25, 379-395. [CrossRef]

46. Lee, D.X.; Xia, W.S.; Zhang, J.L. Enzymatic preparation of chitooligosaccharides by commercial lipase. Food Chem. 2008, 111, 291-295. [CrossRef] [PubMed]

47. Shin, S.S.; Lee, Y.C.; Chan, L. The degradation of chitosan with the aid of lipase from Rhizopus japonicus for the production of soluble chitosan. J. Food Biochem. 2001, 25, 307-321. [CrossRef]

48. Raafat, D.; Sahl, H.G. Chitosan and its antimicrobial potential-A critical literature survey. Microb. Biotechnol. 2009 , 2, 186-201. [CrossRef] [PubMed]

49. Raafat, D.; Von Bargen, K.; Haas, A.; Sahl, H.G. Insights into the mode of action of chitosan as an antibacterial compound. Appl. Environ. Microbiol. 2008, 74, 3764-3773. [CrossRef]

50. Yildirim-Aksoy, M.; Beck, B.H. Antimicrobial activity of chitosan and a chitosan oligomer against bacterial pathogens of warmwater fish. J. Appl. Microbiol. 2017, 122, 1570-1578. [CrossRef]

51. Tayel, A.A.; Moussa, S.; El-Tras, W.F.; Knittel, D.; Opwis, K.; Schollmeyer, E. Anticandidal action of fungal chitosan against Candida albicans. Int. J. Biol. Macromol. 2010, 47, 454-457. [CrossRef] [PubMed]

52. Hosseinnejad, M.; Jafari, S.M. Evaluation of different factors affecting antimicrobial properties of chitosan. Int. J. Biol. Macromol. 2016, 85, 467-475. [CrossRef]

53. Seyfarth, F.; Schliemann, S.; Elsner, P.; Hipler, U.C. Antifungal effect of high- and low-molecular-weight chitosan hydrochloride, carboxymethyl chitosan, chitosan oligosaccharide and $N$-acetyl-D-glucosamine against Candida albicans, Candida krusei and Candida glabrata. Int. J. Pharm. 2008, 353, 139-148. [CrossRef]

54. Bano, I.; Arshad, M.; Yasin, T.; Ghauri, M.A.; Younus, M. Chitosan: A potential biopolymer for wound management. Int. J. Biol. Macromol. 2017, 102, 380-383. [CrossRef]

55. Younes, I.; Rinaudo, M. Chitin and chitosan preparation from marine sources. Structure, properties and applications. Mar. Drugs 2015, 13, 1133-1174. [CrossRef]

56. Abd El-Hack, M.E.; El-Saadony, M.T.; Shafi, M.E.; Zabermawi, N.M.; Arif, M.; Batiha, G.E.; Khafaga, A.F.; Abd El-Hakim, Y.M.; Al-Sagheer, A.A. Antimicrobial and antioxidant properties of chitosan and its derivatives and their applications: A review. Int. J. Biol. Macromol. 2020, 164, 2726-2744. [CrossRef] [PubMed]

57. Chien, R.C.; Yen, M.T.; Mau, J.L. Antimicrobial and antitumor activities of chitosan from shiitake stipes, compared to commercial chitosan from crab shells. Carbohydr. Polym. 2016, 138, 259-264. [CrossRef] [PubMed]

58. Sarhan, W.A.; Azzazy, H.M.E.; El-Sherbiny, I.M. Honey/Chitosan Nanofiber Wound Dressing Enriched with Allium sativum and Cleome droserifolia: Enhanced Antimicrobial and Wound Healing Activity. ACS Appl. Mater. Interfaces 2016, 8, 6379-6390. [CrossRef] [PubMed]

59. Han, F.; Dong, Y.; Song, A.; Yin, R.; Li, S. Alginate/chitosan based bi-layer composite membrane as potential sustained-release wound dressing containing ciprofloxacin hydrochloride. Appl. Surf. Sci. 2014, 311, 626-634. [CrossRef] 
60. Mukhtar Ahmed, K.B.; Khan, M.M.A.; Siddiqui, H.; Jahan, A. Chitosan and its oligosaccharides, a promising option for sustainable crop production- a review. Carbohydr. Polym. 2020, 227. [CrossRef] [PubMed]

61. No, H.K.; Kim, S.H.; Lee, S.H.; Park, N.Y.; Prinyawiwatkul, W. Stability and antibacterial activity of chitosan solutions affected by storage temperature and time. Carbohydr. Polym. 2006, 65, 174-178. [CrossRef]

62. Lee, B.C.; Kim, M.S.; Choi, S.H.; Kim, K.Y.; Kim, T.S. In vitro and in vivo antimicrobial activity of water-soluble chitosan oligosaccharides against Vibrio vulnificus. Int. J. Mol. Med. 2009, 24, 327-333.

63. Sun, Z.; Shi, C.; Wang, X.; Fang, Q.; Huang, J. Synthesis, characterization, and antimicrobial activities of sulfonated chitosan. Carbohydr. Polym. 2017, 155, 321-328. [CrossRef]

64. Sadeghi, A.M.M.; Dorkoosh, F.A.; Avadi, M.R.; Saadat, P.; Rafiee-Tehrani, M.; Junginger, H.E. Preparation, characterization and antibacterial activities of chitosan, N-trimethyl chitosan (TMC) and N-diethylmethyl chitosan (DEMC) nanoparticles loaded with insulin using both the ionotropic gelation and polyelectrolyte complexation methods. Int. J. Pharm. 2008, 355, 299-306. [CrossRef]

65. Si, Z.; Hou, Z.; Vikhe, Y.S.; Thappeta, K.R.V.; Marimuthu, K.; De, P.P.; Ng, O.T.; Li, P.; Zhu, Y.; Pethe, K.; et al. Antimicrobial effect of a novel chitosan derivative and its synergistic effect with antibiotics. ACS Appl. Mater. Interfaces 2021, 13, 3237-3245. [CrossRef]

66. Hamed, A.A.; Abdelhamid, I.A.; Saad, G.R.; Elkady, N.A.; Elsabee, M.Z. Synthesis, characterization and antimicrobial activity of a novel chitosan Schiff bases based on heterocyclic moieties. Int. J. Biol. Macromol. 2020, 153, 492-501. [CrossRef] [PubMed]

67. Sirisinha, C.; Sittichokchuchai, W. Molecular weight effect on antimicrobial activity of chitosan treated cotton fabrics. J. Appl. Polym. Sci. 2001, 80, 2495-2501.

68. No, H.K.; Young Park, N.; Ho Lee, S.; Meyers, S.P. Antibacterial activity of chitosans and chitosan oligomers with different molecular weights. Int. J. Food Microbiol. 2002, 74, 65-72. [CrossRef]

69. Omura, Y.; Shigemoto, M.; Akiyama, T.; Saimoto, H.; Shigemasa, Y.; Nakamura, I.; Tsuchido, T. Antimicrobial activity of chitosan with different degrees of acetylation and molecular weights. Biocontrol Sci. 2003, 8, 25-30. [CrossRef]

70. Šimůnek, J.; Brandysová, V.; Koppová, I.; Šimůnek, J., Jr. The antimicrobial action of chitosan, low molar mass chitosan, and chitooligosaccharides on human colonic bacteria. Folia Microbiol. 2012, 57, 341-345. [CrossRef]

71. Tokura, S.; Ueno, K.; Miyazaki, S.; Nishi, N. Molecular Weight Dependent Antimicrobial Activity by Chitosan. Macromol. Symp. 1997, 120, 1-9. [CrossRef]

72. Liu, N.; Chen, X.G.; Park, H.J.; Liu, C.G.; Liu, C.S.; Meng, X.H.; Yu, L.J. Effect of MW and concentration of chitosan on antibacterial activity of Escherichia coli. Carbohydr. Polym. 2006, 64, 60-65. [CrossRef]

73. Chang, S.H.; Lin, H.T.V.; Wu, G.J.; Tsai, G.J. pH Effects on solubility, zeta potential, and correlation between antibacterial activity and molecular weight of chitosan. Carbohydr. Polym. 2015, 134, 74-81. [CrossRef] [PubMed]

74. Mellegård, H.; Strand, S.P.; Christensen, B.E.; Granum, P.E.; Hardy, S.P. Antibacterial activity of chemically defined chitosans: Influence of molecular weight, degree of acetylation and test organism. Int. J. Food Microbiol. 2011, 148, 48-54. [CrossRef] [PubMed]

75. Younes, I.; Sellimi, S.; Rinaudo, M.; Jellouli, K.; Nasri, M. Influence of acetylation degree and molecular weight of homogeneous chitosans on antibacterial and antifungal activities. Int. J. Food Microbiol. 2014, 185, 57-63. [CrossRef] [PubMed]

76. Qin, C.; Li, H.; Xiao, Q.; Liu, Y.; Zhu, J.; Du, Y. Water-solubility of chitosan and its antimicrobial activity. Carbohydr. Polym. 2006, 63, 367-374. [CrossRef]

77. Sánchez, Á.; Mengíbar, M.; Rivera-Rodríguez, G.; Moerchbacher, B.; Acosta, N.; Heras, A. The effect of preparation processes on the physicochemical characteristics and antibacterial activity of chitooligosaccharides. Carbohydr. Polym. 2017, 157, 251-257. [CrossRef]

78. Giacco, F.; Brownlee, M. Oxidative stress and diabetic complications. Circ. Res. 2010, 107, 1058-1070. [CrossRef]

79. Singh, A.; Kukreti, R.; Saso, L.; Kukreti, S. Oxidative stress: A key modulator in neurodegenerative diseases. Molecules 2019, 24, 1583. [CrossRef]

80. Hayes, J.D.; Dinkova-Kostova, A.T.; Tew, K.D. Oxidative Stress in Cancer. Cancer Cell 2020, 38, 167-197. [CrossRef]

81. Kogan, G.; Skorik, Y.A.; Žitňanová, I.; Križková, L.; Ďuračková, Z.; Gomes, C.A.R.; Yatluk, Y.G.; Krajčovič, J. Antioxidant and antimutagenic activity of N-(2-carboxyethyl) chitosan. Toxicol. Appl. Pharmacol. 2004, 201, 303-310. [CrossRef]

82. Xing, R.; Yu, H.; Liu, S.; Zhang, W.; Zhang, Q.; Li, Z.; Li, P. Antioxidant activity of differently regioselective chitosan sulfates in vitro. Bioorgan. Med. Chem. 2005, 13, 1387-1392. [CrossRef]

83. Zhou, J.; Wen, B.; Xie, H.; Zhang, C.; Bai, Y.; Cao, H.; Che, Q.; Guo, J.; Su, Z. Advances in the preparation and assessment of the biological activities of chitosan oligosaccharides with different structural characteristics. Food. Funct. 2021, 12, 926-951. [CrossRef]

84. Ngo, D.H.; Qian, Z.J.; Vo, T.S.; Ryu, B.; Ngo, D.N.; Kim, S.K. Antioxidant activity of gallate-chitooligosaccharides in mouse macrophage RAW264.7 cells. Carbohydr. Polym. 2011, 84, 1282-1288. [CrossRef]

85. Ngo, D.H.; Qian, Z.J.; Ngo, D.N.; Vo, T.S.; Wijesekara, I.; Kim, S.K. Gallyl chitooligosaccharides inhibit intracellular free radical-mediated oxidation. Food Chem. 2011, 128, 974-981. [CrossRef]

86. Eom, T.K.; Senevirathne, M.; Kim, S.K. Synthesis of phenolic acid conjugated chitooligosaccharides and evaluation of their antioxidant activity. Environ. Toxicol. Pharmacol. 2012, 34, 519-527. [CrossRef] [PubMed]

87. Sun, T.; Zhou, D.; Xie, J.; Mao, F. Preparation of chitosan oligomers and their antioxidant activity. Eur. Food Res. Technol. 2007, 225, 451-456. [CrossRef]

88. Pu, S.; Li, J.; Sun, L.; Zhong, L.; Ma, Q. An in vitro comparison of the antioxidant activities of chitosan and green synthesized gold nanoparticles. Carbohydr. Polym. 2019, 211, 161-172. [CrossRef] [PubMed] 
89. Chang, S.H.; Lin, Y.Y.; Wu, G.J.; Huang, C.H.; Tsai, G.J. Effect of chitosan molecular weight on anti-inflammatory activity in the RAW 264.7 macrophage model. Int. J. Biol. Macromol. 2019, 131, 167-175. [CrossRef]

90. Santos-Moriano, P.; Fernandez-Arrojo, L.; Mengibar, M.; Belmonte-Reche, E.; Peñalver, P.; Acosta, F.N.; Ballesteros, A.O.; Morales, J.C.; Kidibule, P.; Fernandez-Lobato, M.; et al. Enzymatic production of fully deacetylated chitooligosaccharides and their neuroprotective and anti-inflammatory properties. Biocatal. Biotransform. 2018, 36, 57-67. [CrossRef]

91. Santos-Moriano, P.; Kidibule, P.; Míguez, N.; Fernández-Arrojo, L.; Ballesteros, A.O.; Fernández-Lobato, M.; Plou, F.J. Tailored enzymatic synthesis of chitooligosaccharides with different deacetylation degrees and their anti-inflammatory activity. Catalysts 2019, 9, 405. [CrossRef]

92. Lee, S.H.; Senevirathne, M.; Ahn, C.B.; Kim, S.K.; Je, J.Y. Factors affecting anti-inflammatory effect of chitooligosaccharides in lipopolysaccharides-induced RAW264.7 macrophage cells. Bioorg. Med. Chem. Lett. 2009, 19, 6655-6658. [CrossRef]

93. Mao, S.; Wang, B.; Yue, L.; Xia, W. Effects of citronellol grafted chitosan oligosaccharide derivatives on regulating antiinflammatory activity. Carbohydr. Polym. 2021, 262, 117972. [CrossRef]

94. Sánchez, Á.; Mengíbar, M.; Fernández, M.; Alemany, S.; Heras, A.; Acosta, N. Influence of preparation methods of chitooligosaccharides on their physicochemical properties and their anti-inflammatory effects in mice and in RAW264.7 macrophages. Mar. Drugs 2018, 16, 430. [CrossRef]

95. Watanabe, K. Photochemistry on nanoparticles. In Encyclopedia of Interfacial Chemistry: Surface Science and Electrochemistry; Elsevier: Amsterdam, The Netherlands, 2018; pp. 563-572. [CrossRef]

96. Pal, D.; Saha, S. Current status and prospects of chitosan: Metal nanoparticles and their applications as nanotheranostic agents. In Nanotheranostics: Applications and Limitations; Springer International Publishing: Berlin/Heidelberg, Germany, 2019 ; pp. 79-114. [CrossRef]

97. Esumi, K.; Takei, N.; Yoshimura, T. Antioxidant-potentiality of gold-chitosan nanocomposites. Colloids Surf. B Biointerfaces 2003, 32, 117-123. [CrossRef]

98. Khan, Z. Chitosan capped Au@Pd@Ag trimetallic nanoparticles: Synthesis, stability, capping action and adsorbing activities. Int. J. Biol. Macromol. 2020, 153, 545-560. [CrossRef]

99. Firoozi, S.; Jamzad, M.; Yari, M. Biologically synthesized silver nanoparticles by aqueous extract of Satureja intermedia C.A. Mey and the evaluation of total phenolic and flavonoid contents and antioxidant activity. J. Nanostruct. Chem. 2016, 6, 357-364. [CrossRef]

100. Guo, Y.; Yan, H. Preparation and characterization of heparin-stabilized gold nanoparticles. J. Carbohydr. Chem. 2008, 27, 309-319. [CrossRef]

101. Cheng, K.M.; Hung, Y.W.; Chen, C.C.; Liu, C.C.; Young, J.J. Green synthesis of chondroitin sulfate-capped silver nanoparticles: Characterization and surface modification. Carbohydr. Polym. 2014, 110, 195-202. [CrossRef] [PubMed]

102. Mukherjee, K.; Gupta, R.; Kumar, G.; Kumari, S.; Biswas, S.; Padmanabhan, P. Synthesis of silver nanoparticles by Bacillus clausii and computational profiling of nitrate reductase enzyme involved in production. J. Genet. Eng. Biotechnol. 2018, 16, 527-536. [CrossRef] [PubMed]

103. Kumar, S.A.; Abyaneh, M.K.; Gosavi, S.W.; Kulkarni, S.K.; Pasricha, R.; Ahmad, A.; Khan, M.I. Nitrate reductase-mediated synthesis of silver nanoparticles from $\mathrm{AgNO}_{3}$. Biotechnol. Lett. 2007, 29, 439-445. [CrossRef] [PubMed]

104. Hansen, H.E.; Seland, F.; Sunde, S.; Burheim, O.S.; Pollet, B.G. Two routes for sonochemical synthesis of platinum nanoparticles with narrow size distribution. Mater. Adv. 2021, 2, 1962-1971. [CrossRef]

105. Abedini, A.; Daud, A.R.; Hamid, M.A.A.; Othman, N.K.; Saion, E. A review on radiation-induced nucleation and growth of colloidal metallic nanoparticles. Nanoscale Res. Lett. 2013, 8, 474. [CrossRef] [PubMed]

106. Nasretdinova, G.R.; Fazleeva, R.R.; Mukhitova, R.K.; Nizameev, I.R.; Kadirov, M.K.; Ziganshina, A.Y.; Yanilkin, V.V. Electrochemical synthesis of silver nanoparticles in solution. Electrochem. Commun. 2015, 50, 69-72. [CrossRef]

107. Bonyár, A.; Csarnovics, I.; Veres, M.; Himics, L.; Csik, A.; Kámán, J.; Balázs, L.; Kökényesi, S. Investigation of the performance of thermally generated gold nanoislands for LSPR and SERS applications. Sens. Actuators B Chem. 2018, 255, 433-439. [CrossRef]

108. Kang, H.; Buchman, J.T.; Rodriguez, R.S.; Ring, H.L.; He, J.; Bantz, K.C.; Haynes, C.L. Stabilization of Silver and Gold Nanoparticles: Preservation and Improvement of Plasmonic Functionalities. Chem. Rev. 2019, 119, 664-699. [CrossRef]

109. Huang, H.; Yuan, Q.; Yang, X. Preparation and characterization of metal-chitosan nanocomposites. Colloids Surf. B Biointerfaces 2004, 39, 31-37. [CrossRef]

110. Phan, T.T.V.; Nguyen, Q.V.; Huynh, T.C. Simple, green, and low-temperature method for preparation of palladium nanoparticles with controllable sizes and their characterizations. J. Nanopart. Res. 2020, 22, 73. [CrossRef]

111. Phan, T.T.V.; Hoang, G.; Nguyen, V.T.; Nguyen, T.P.; Kim, H.H.; Mondal, S.; Manivasagan, P.; Moorthy, M.S.; Lee, K.D.; Junghwan, $\mathrm{O}$. Chitosan as a stabilizer and size-control agent for synthesis of porous flower-shaped palladium nanoparticles and their applications on photo-based therapies. Carbohydr. Polym. 2019, 205, 340-352. [CrossRef] [PubMed]

112. Gaikwad, G.; Bangde, P.; Rane, K.; Stenberg, J.; Borde, L.; Bhagwat, S.; Dandekar, P.; Jain, R. Continuous production and separation of new biocompatible palladium nanoparticles using a droplet microreactor. Microfluid. Nanofluid. 2021, 25, 27. [CrossRef]

113. Adlim, M.; Abu Bakar, M.; Liew, K.Y.; Ismail, J. Synthesis of chitosan-stabilized platinum and palladium nanoparticles and their hydrogenation activity. J. Mol. Catal. A Chem. 2004, 212, 141-149. [CrossRef]

114. Kleszcz, K.; Hebda, M.; Kyzioł, A.; Krawiec, H.; Kyzioł, K. Towards prevention of biofilm formation: Ti6Al7Nb modified with nanocomposite layers of chitosan and Ag/Au nanoparticles. Appl. Surf. Sci. 2021, 557, 149795. [CrossRef] 
115. Hortigüela, M.J.; Aranaz, I.; Gutiérrez, M.C.; Ferrer, M.L.; Del Monte, F. Chitosan gelation induced by the in situ formation of gold nanoparticles and its processing into macroporous scaffolds. Biomacromolecules 2011, 12, 179-186. [CrossRef]

116. Abrica-González, P.; Zamora-Justo, J.A.; Sotelo-López, A.; Vázquez-Martínez, G.R.; Balderas-López, J.A.; Muñoz-Diosdado, A.; Ibáñez-Hernández, M. Gold nanoparticles with chitosan, $N$-acylated chitosan, and chitosan oligosaccharide as DNA carriers. Nanoscale Res. Lett. 2019, 14, 258. [CrossRef] [PubMed]

117. Sun, L.; Li, J.; Cai, J.; Zhong, L.; Ren, G.; Ma, Q. One pot synthesis of gold nanoparticles using chitosan with varying degree of deacetylation and molecular weight. Carbohydr. Polym. 2017, 178, 105-114. [CrossRef] [PubMed]

118. Twu, Y.K.; Chen, Y.W.; Shih, C.M. Preparation of silver nanoparticles using chitosan suspensions. Powder Technol. 2008, 185, 251-257. [CrossRef]

119. Murugadoss, A.; Chattopadhyay, A. A 'green' chitosan-silver nanoparticle composite as a heterogeneous as well as microheterogeneous catalyst. Nanotechnology 2008, 19, 015603. [CrossRef] [PubMed]

120. Kalaivani, R.; Maruthupandy, M.; Muneeswaran, T.; Hameedha Beevi, A.; Anand, M.; Ramakritinan, C.M.; Kumaraguru, A.K. Synthesis of chitosan mediated silver nanoparticles (Ag NPs) for potential antimicrobial applications. Front. Lab. Med. 2018, 2, 30-35. [CrossRef]

121. Karthik, C.S.; Chethana, M.H.; Manukumar, H.M.; Ananda, A.P.; Sandeep, S.; Nagashree, S.; Mallesha, L.; Mallu, P.; Jayanth, H.S.; Dayananda, B.P. Synthesis and characterization of chitosan silver nanoparticle decorated with benzodioxane coupled piperazine as an effective anti-biofilm agent against MRSA: A validation of molecular docking and dynamics. Int. J. Biol. Macromol. 2021, 181, 540-551. [CrossRef]

122. Pandey, I.; Chandra, A. Temperature-induced changes in polymer-based fractal patterns due to Ag metal aggregation. Appl. Phys. A 2021, 127, 369. [CrossRef]

123. Aranaz, I.; Castro, C.; Heras, A.; Acosta, N. On the ability of low molecular weight chitosan enzymatically depolymerized to produce and stabilize silver nanoparticles. Biomimetics 2018, 3, 21. [CrossRef]

124. Aranaz, I.; Alcántara, A.R.; Heras, A.; Acosta, N. Efficient reduction of Toluidine Blue O dye using silver nanoparticles synthesized by low molecular weight chitosans. Int. J. Biol. Macromol. 2019, 131, 682-690. [CrossRef]

125. Romero-Fernández, M.; Paradisi, F. Protein immobilization technology for flow biocatalysis. Curr. Opin. Chem. Biol. 2020, 55, 1-8. [CrossRef] [PubMed]

126. Boudrant, J.; Woodley, J.M.; Fernandez-Lafuente, R. Parameters necessary to define an immobilized enzyme preparation. Process Biochem. 2020, 90, 66-80. [CrossRef]

127. Thompson, M.P.; Penafiel, I.; Cosgrove, S.C.; Turner, N.J. Biocatalysis using immobilized enzymes in continuous flow for the synthesis of fine chemicals. Org. Process Res. Dev. 2019, 23, 9-18. [CrossRef]

128. Thompson, M.P.; Derrington, S.R.; Heath, R.S.; Porter, J.L.; Mangas-Sanchez, J.; Devine, P.N.; Truppo, M.D.; Turner, N.J. A generic platform for the immobilisation of engineered biocatalysts. Tetrahedron 2019, 75, 327-334. [CrossRef]

129. Reis, C.L.B.; de Sousa, E.Y.A.; Serpa, J.D.; Oliveira, R.C.; dos Santos, J.C.S. Design of immobilized enzyme biocatalysts: Drawbacks and opportunities. Quim. Nova 2019, 42, 768-783. [CrossRef]

130. Ravindran, R.; Jaiswal, A.K. Current Advances in Immobilization Techniques of Enzymes. In Enzymatic Fuel Cells: Materials and Applications; Inamuddin, Ahmer, M.F., Ahamed, M.I., Asiri, A.M., Eds.; Materials Research Forum Llc: Millersville, PA, USA, 2019; Volume 44, pp. 51-72.

131. Goncalves, M.C.P.; Kieckbusch, T.G.; Perna, R.F.; Fujimoto, J.T.; Morales, S.A.V.; Romanelli, J.P. Trends on enzyme immobilization researches based on bibliometric analysis. Process Biochem. 2019, 76, 95-110. [CrossRef]

132. Fernandez-Lafuente, R. Editorial for Special Issue: Enzyme Immobilization and Its Applications. Molecules 2019, 24, 4. [CrossRef]

133. Basso, A.; Serban, S. Industrial applications of immobilized enzymes-A review. Mol. Catal. 2019, 479, 110607. [CrossRef]

134. Ahmad, A.; Javed, M.R.; Ibrahim, M.; Sajid, A.; Hussain, K.; Kaleem, M.; Fatima, H.M.; Nadeem, H. Methods of Enzyme Immobilization on Various Supports. In Enzymatic Fuel Cells: Materials and Applications; Inamuddin, Ahmer, M.F., Ahamed, M.I., Asiri, A.M., Eds.; Materials Research Forum Llc: Millersville, PA, USA, 2019; Volume 44, pp. 1-28.

135. Grunwald, P. Immobilized Biocatalysts. Catalysts 2018, 8, 7. [CrossRef]

136. Corici, L.; Ferrario, V.; Pellis, A.; Ebert, C.; Lotteria, S.; Cantone, S.; Voinovich, D.; Gardossi, L. Large scale applications of immobilized enzymes call for sustainable and inexpensive solutions: Rice husks as renewable alternatives to fossil-based organic resins. RSC Adv. 2016, 6, 63256-63270. [CrossRef]

137. Bolivar, J.M.; Eisl, I.; Nidetzky, B. Advanced characterization of immobilized enzymes as heterogeneous biocatalysts. Catal. Today 2016, 259, 66-80. [CrossRef]

138. Eş, I.; Vieira, J.D.G.; Amaral, A.C. Principles, techniques, and applications of biocatalyst immobilization for industrial application. Appl. Microbiol. Biotechnol. 2015, 99, 2065-2082. [CrossRef] [PubMed]

139. Bezerra, C.S.; Lemos, C.; de Sousa, M.; Goncalves, L.R.B. Enzyme immobilization onto renewable polymeric matrixes: Past, present, and future trends. J. Appl. Polym. Sci. 2015, 132, 15. [CrossRef]

140. Sheldon, R.A.; van Pelt, S. Enzyme immobilisation in biocatalysis: Why, what and how. Chem. Soc. Rev. 2013, $42,6223-6235$. [CrossRef]

141. Mohamad, N.R.; Marzuki, N.H.C.; Buang, N.A.; Huyop, F.; Wahab, R.A. An overview of technologies for immobilization of enzymes and surface analysis techniques for immobilized enzymes. Biotechnol. Biotechnol. Equip. 2015, 29, 205-220. [CrossRef] 
142. Sirisha, V.L.; Jain, A.; Jain, A. Enzyme Immobilization: An Overview on Methods, Support Material, and Applications of Immobilized Enzymes. In Advances in Food and Nutrition Research; Academic Press Inc.: Cambridge, MA, USA, 2016; Volume 79, pp. 179-211.

143. Krajewska, B. Application of chitin- and chitosan-based materials for enzyme immobilizations: A review. Enzyme Microb. Technol. 2004, 35, 126-139. [CrossRef]

144. Peniche, C.; Arguelles-Monal, W.; Peniche, H.; Acosta, N. Chitosan: An attractive biocompatible polymer for microencapsulation. Macromol. Biosci. 2003, 3, 511-520. [CrossRef]

145. Hoven, V.P.; Tangpasuthadol, V.; Angkitpaiboon, Y.; Vallapa, N.; Kiatkamjornwong, S. Surface-charged chitosan: Preparation and protein adsorption. Carbohydr. Polym. 2007, 68, 44-53. [CrossRef]

146. Biro, E.; Nemeth, A.S.; Sisak, C.; Feczko, T.; Gyenis, J. Preparation of chitosan particles suitable for enzyme immobilization. J. Biochem. Biophys. Methods 2008, 70, 1240-1246. [CrossRef] [PubMed]

147. Verma, M.L.; Kumar, S.; Das, A.; Randhawa, J.S.; Chamundeeswari, M. Chitin and chitosan-based support materials for enzyme immobilization and biotechnological applications. Environ. Chem. Lett. 2020, 18, 315-323. [CrossRef]

148. Wang, D.Q.; Jiang, W.F. Preparation of chitosan-based nanoparticles for enzyme immobilization. Int. J. Biol. Macromol. 2019, 126, 1125-1132. [CrossRef]

149. Malmiri, H.J.; Jahanian, M.A.G.; Berenjian, A. Potential applications of chitosan nanoparticles as novel support in enzyme immobilization. Am. J. Biochem. Biotechnol. 2012, 8, 203-219.

150. Aranaz, I.; Acosta, N.; Heras, A. Encapsulation of an Agrobacterium radiobacter extract containing $D$-hydantoinase and $D$ carbamoylase activities into alginate-chitosan polyelectrolyte complexes. Preparation of the biocatalyst. J. Mol. Catal. B Enzym. 2009, 58, 54-64. [CrossRef]

151. Aranaz, I.; Acosta, N.; Heras, A. Enzymatic D-p-hydrophenyl glycine synthesis using chitin and chitosan as supports for biocatalyst immobilization. Biocatal. Biotransform. 2018, 36, 89-101. [CrossRef]

152. Aranaz, I.; Acosta, N.; Férnandez-Valle, M.E.; Heras, A. Optimization of $D$-amino acid production catalyzed by immobilized multi-enzyme system in polyelectrolyte complex gel capsules. J. Mol. Catal. B Enzym. 2015, 121, 45-52. [CrossRef]

153. Aranaz, I.; Ramos, V.; De La Escalera, S.; Heras, A. Co-immobilization of D-hydantoinase and D-carboamylase on chitin: Application to the synthesis of $p$-hydroxyphenylglycine. Biocatal. Biotransform. 2003, 21, 349-356. [CrossRef]

154. Volpato, G.; Rodrigues, R.C.; Fernandez-Lafuente, R. Use of enzymes in the production of semi-synthetic penicillins and cephalosporins: Drawbacks and perspectives. Curr. Med. Chem. 2010, 17, 3855-3873. [CrossRef] [PubMed]

155. Mateo, C.; Abian, O.; Grazú, V.; Fernández-Lorente, G.; Palomo, J.M.; Fuentes, M.; Segura, R.L.; Montes, T.; López-Gallego, F.; Wilson, L.; et al. Recent advances in the industrial enzymatic synthesis of semi-synthetic $\beta$-lactam antibiotics. Med. Chem. Rev. Online 2005, 2, 207-218. [CrossRef]

156. Rodriguez-Herrera, R.; Puc, L.E.C.; Sobrevilla, J.M.V.; Luque, D.; Cardona-Felix, C.S.; Aguilar-González, C.N.; Flores-Gallegos, A.C. Enzymes in the pharmaceutical industry for $\beta$-lactam antibiotic production. In Enzymes in Food Biotechnology: Production, Applications, and Future Prospects; Elsevier: Amsterdam, The Netherlands, 2018; pp. 627-643. [CrossRef]

157. Farhadian, S.; Shareghi, B.; Tirgir, F.; Reiisi, S.; Dehkordi, N.G.; Momeni, L.; Heidari, E. Design, synthesis, and anti-gastric cancer activity of novel 2,5-diketopiperazine. J. Mol. Liq. 2019, 294, 111585. [CrossRef]

158. Lukasevics, L.; Cizikovs, A.; Grigorjeva, L. Synthesis of 3-Hydroxymethyl Isoindolinones via Cobalt-Catalyzed C(sp2)-H Carbonylation of Phenylglycinol Derivatives. Org. Lett. 2020, 22, 2720-2723. [CrossRef] [PubMed]

159. Wang, Z.X.; Xiang, J.C.; Cheng, Y.; Ma, J.T.; Wu, Y.D.; Wu, A.X. Direct Biomimetic Synthesis of $\beta$-Carboline Alkaloids from Two Amino Acids. J. Org. Chem. 2018, 83, 12247-12254. [CrossRef] [PubMed]

160. Xiang, J.C.; Wang, Z.X.; Cheng, Y.; Xia, S.Q.; Wang, M.; Tang, B.C.; Wu, Y.D.; Wu, A.X. Divergent Synthesis of Functionalized Quinolines from Aniline and Two Distinct Amino Acids. J. Org. Chem. 2017, 82, 9210-9216. [CrossRef] [PubMed]

161. Gräßle, S.; Vanderheiden, S.; Hodapp, P.; Bulat, B.; Nieger, M.; Jung, N.; Bräse, S. Solid Phase Synthesis of (Benzannelated) SixMembered Heterocycles via Cyclative Cleavage of Resin-Bound Pseudo-Oxazolones. Org. Lett. 2016, 18, 3598-3601. [CrossRef] [PubMed]

162. Clemente-Jiménez, J.M.; Martínez-Rodríguez, S.; Rodríguez-Vico, F.; Heras-Vázquez, F.J.L. Optically pure $\alpha$-amino acids production by the "Hydantoinase Process". Recent Pat. Biotechnol. 2008, 2, 35-46. [PubMed]

163. Rodríguez-Alonso, M.J.; Clemente-Jiménez, J.M.; Rodríguez-Vico, F.; Las Heras- Vázquez, F.J. Rational re-design of the "doubleracemase hydantoinase process" for optically pure production of natural and non-natural l-amino acids. Biochem. Eng. J. 2015, 101, 68-76. [CrossRef]

164. Aranaz, I.; Acosta, N.; Heras, A. Synthesis of p-hydroxyphenylglicine by cell extract from Agrobaterium radiobacter encapsulated in alginate capsules. Enzym. Microb. Technol. 2006, 39, 215-221. [CrossRef]

165. Fernández-Lucas, J.; Harris, R.; Mata-Casar, I.; Heras, A.; De La Mata, I.; Arroyo, M. Magnetic chitosan beads for covalent immobilization of nucleoside 2 -deoxyribosyltransferase: Application in nucleoside analogues synthesis. J. Ind. Microbiol. Biotechnol. 2013, 40, 955-966. [CrossRef] [PubMed]

166. Bernkop-Schnürch, A.; Dünnhaupt, S. Chitosan-based drug delivery systems. Eur. J. Pharm. Biopharm. 2012, 81, 463-469. [CrossRef]

167. Ojeda-Hernández, D.D.; Canales-Aguirre, A.A.; Matias-Guiu, J.; Gomez-Pinedo, U.; Mateos-Díaz, J.C. Potential of Chitosan and Its Derivatives for Biomedical Applications in the Central Nervous System. Front. Bioeng. Biotechnol. 2020, 8, 389. [CrossRef] 
168. Noel, S.P.; Courtney, H.; Bumgardner, J.D.; Haggard, W.O. Chitosan films: A potential local drug delivery system for antibiotics. Clin. Orthop. Relat. Res. 2008, 466, 1377-1382. [CrossRef]

169. Affes, S.; Aranaz, I.; Acosta, N.; Heras, Á.; Nasri, M.; Maalej, H. Chitosan derivatives-based films as pH-sensitive drug delivery systems with enhanced antioxidant and antibacterial properties. Int. J. Biol. Macromol. 2021, 182, 730-742. [CrossRef] [PubMed]

170. Aranaz, I.; Harris, R.; Navarro-García, F.; Heras, A.; Acosta, N. Chitosan based films as supports for dual antimicrobial release. Carbohydr. Polym. 2016, 146, 402-410. [CrossRef] [PubMed]

171. Lozano-Navarro, J.I.; Díaz-Zavala, N.P.; Velasco-Santos, C.; Martínez-Hernández, A.L.; Tijerina-Ramos, B.I.; García-Hernández, M.; Rivera-Armenta, J.L.; Páramo-García, U.; Reyes-de la Torre, A.I. Antimicrobial, optical and mechanical properties of Chitosan-Starch films with natural extracts. Int. J. Mol. Sci. 2017, 18, 997. [CrossRef] [PubMed]

172. Noel, S.P.; Courtney, H.S.; Bumgardner, J.D.; Haggard, W.O. Chitosan sponges to locally deliver amikacin and vancomycin: A pilot in vitro evaluation. Clin. Orthop. Relat. Res. 2010, 468, 2074-2080. [CrossRef] [PubMed]

173. Stinner, D.J.; Noel, S.P.; Haggard, W.O.; Watson, J.T.; Wenke, J.C. Local antibiotic delivery using tailorable chitosan sponges: The future of infection control? J. Orthop. Trauma 2010, 24, 592-597. [CrossRef]

174. Yilgor, P.; Tuzlakoglu, K.; Reis, R.L.; Hasirci, N.; Hasirci, V. Incorporation of a sequential BMP-2/BMP-7 delivery system into chitosan-based scaffolds for bone tissue engineering. Biomaterials 2009, 30, 3551-3559. [CrossRef]

175. Liu, F.; Li, W.; Liu, H.; Yuan, T.; Yang, Y.; Zhou, W.; Hu, Y.; Yang, Z. Preparation of 3D Printed Chitosan/Polyvinyl Alcohol Double Network Hydrogel Scaffolds. Macromol. Biosci. 2021, 21, 2000398. [CrossRef]

176. Ma, S.; Moser, D.; Han, F.; Leonhard, M.; Schneider-Stickler, B.; Tan, Y. Preparation and antibiofilm studies of curcumin loaded chitosan nanoparticles against polymicrobial biofilms of Candida albicans and Staphylococcus aureus. Carbohydr. Polym. 2020, 241, 116254. [CrossRef]

177. Bartos, C.; Varga, P.; Szabó-Révész, P.; Ambrus, R. Physico-chemical and in vitro characterization of chitosan-based microspheres intended for nasal administration. Pharmaceutics 2021, 13, 608. [CrossRef] [PubMed]

178. Zeng, W.; Chang, Z.; Liu, Z.; Zhu, L.; Wang, M.; Hao, D.; He, B. Controlled delivery of bioactive BDNF for potential treatment of peripheral nerve injury. Polym. Degrad. Stab. 2020, 181, 109296. [CrossRef]

179. Aranaz, I.; Paños, I.; Peniche, C.; Heras, Á.; Acosta, N. Chitosan spray-dried microparticles for controlled delivery of venlafaxine hydrochloride. Molecules 2017, 22, 1980. [CrossRef] [PubMed]

180. Gull, N.; Khan, S.M.; Butt, O.M.; Islam, A.; Shah, A.; Jabeen, S.; Khan, S.U.; Khan, A.; Khan, R.U.; Butt, M.T.Z. Inflammation targeted chitosan-based hydrogel for controlled release of diclofenac sodium. Int. J. Biol. Macromol. 2020, 162, 175-187. [CrossRef] [PubMed]

181. Gao, J.; Liu, R.; Wu, J.; Liu, Z.; Li, J.; Zhou, J.; Hao, T.; Wang, Y.; Du, Z.; Duan, C.; et al. The use of chitosan based hydrogel for enhancing the therapeutic benefits of adipose-derived MSCs for acute kidney injury. Biomaterials 2012, 33, 3673-3681. [CrossRef] [PubMed]

182. Acosta, N.; Sánchez, E.; Calderón, L.; Cordoba-Diaz, M.; Cordoba-Diaz, D.; Dom, S.; Heras, A. Physical stability studies of semi-solid formulations from natural compounds loaded with Chitosan Microspheres. Mar. Drugs 2015, 13, 5901-5919. [CrossRef]

183. Guo, L.; Xia, J.; Yu, S.; Yan, J.; He, F.; Zhang, M.; Fan, Q.; Yang, R.; Zhao, W. Natural edible materials made of protein-functionalized aerogel particles for postprandial hyperglycemia management. Int. J. Biol. Macromol. 2021, 167, 279-288. [CrossRef]

184. López-Iglesias, C.; Barros, J.; Ardao, I.; Monteiro, F.J.; Alvarez-Lorenzo, C.; Gómez-Amoza, J.L.; García-González, C.A Vancomycin-loaded chitosan aerogel particles for chronic wound applications. Carbohydr. Polym. 2019, 204, 223-231. [CrossRef] [PubMed]

185. Wei, S.; Ching, Y.C.; Chuah, C.H. Synthesis of chitosan aerogels as promising carriers for drug delivery: A review. Carbohydr. Polym. 2020, 231, 115744. [CrossRef]

186. Chen, M.; Li, L.; Xia, L.; Jiang, S.; Kong, Y.; Chen, X.; Wang, H. The kinetics and release behaviour of curcumin loaded pH-responsive PLGA/chitosan fibers with antitumor activity against HT-29 cells. Carbohydr. Polym. 2021, 265, 118077. [CrossRef]

187. Kalalinia, F.; Taherzadeh, Z.; Jirofti, N.; Amiri, N.; Foroghinia, N.; Beheshti, M.; Bazzaz, B.S.F.; Hashemi, M.; Shahroodi, A.; Pishavar, E.; et al. Evaluation of wound healing efficiency of vancomycin-loaded electrospun chitosan/poly ethylene oxide nanofibers in full thickness wound model of rat. Int. J. Biol. Macromol. 2021, 177, 100-110. [CrossRef]

188. Gorantla, S.; Dabholkar, N.; Sharma, S.; Rapalli, V.K.; Alexander, A.; Singhvi, G. Chitosan-based microneedles as a potential platform for drug delivery through the skin: Trends and regulatory aspects. Int. J. Biol. Macromol. 2021, 184, 438-453. [CrossRef]

189. Chi, J.; Zhang, X.; Chen, C.; Shao, C.; Zhao, Y.; Wang, Y. Antibacterial and angiogenic chitosan microneedle array patch for promoting wound healing. Bioact. Mater. 2020, 5, 253-259. [CrossRef]

190. Imam, S.S.; Alshehri, S.; Altamimi, M.A.; Hussain, A.; Qamar, W.; Gilani, S.J.; Zafar, A.; Alruwaili, N.K.; Alanazi, S.; Almutairy, B.K. Formulation of piperine-chitosan-coated liposomes: Characterization and in vitro cytotoxic evaluation. Molecules 2021, 26, 3281. [CrossRef] [PubMed]

191. Shukla, S.K.; Chan, A.; Parvathaneni, V.; Gupta, V. Metformin-loaded chitosomes for treatment of malignant pleural mesothelioma-A rare thoracic cancer. Int. J. Biol. Macromol. 2020, 160, 128-141. [CrossRef]

192. Prakash, J.; Prema, D.; Venkataprasanna, K.S.; Balagangadharan, K.; Selvamurugan, N.; Venkatasubbu, G.D. Nanocomposite chitosan film containing graphene oxide/hydroxyapatite/gold for bone tissue engineering. Int. J. Biol. Macromol. 2020, $154,62-71$. [CrossRef] 
193. Kumar, A.; Kaur, H. Sprayed in-situ synthesis of polyvinyl alcohol/chitosan loaded silver nanocomposite hydrogel for improved antibacterial effects. Int. J. Biol. Macromol. 2020, 145, 950-964. [CrossRef] [PubMed]

194. Menazea, A.A.; Eid, M.M.; Ahmed, M.K. Synthesis, characterization, and evaluation of antimicrobial activity of novel Chitosan/Tigecycline composite. Int. J. Biol. Macromol. 2020, 147, 194-199. [CrossRef] [PubMed]

195. European Pharmacopoeia, 10th ed.; Council of Europe, European Directorate for the Quality of Medicines Healthcare: Strasbourg, France, 2019.

196. The United States Pharmacopeial Convention. The United States Pharmacopeia: The National Formulary; The United States Pharmacopeial Convention: Rockville, MD, USA, 2018.

197. Salama, A.H.; Elmotasem, H.; Salama, A.A.A. Nanotechnology based blended chitosan-pectin hybrid for safe and efficient consolidative antiemetic and neuro-protective effect of meclizine hydrochloride in chemotherapy induced emesis. Int. J. Pharm. 2020, 584, 119411. [CrossRef]

198. Saracogullari, N.; Gundogdu, D.; Ozdemir, F.N.; Soyer, Y.; Erel-Goktepe, I. The effect of polyacid on the physical and biological properties of chitosan based layer-by-layer films. Colloids Surf. A Physicochem. Eng. Asp. 2021, 617, 126313. [CrossRef]

199. Mohebali, A.; Abdouss, M. Layered biocompatible $\mathrm{pH}$-responsive antibacterial composite film based on HNT/PLGA/chitosan for controlled release of minocycline as burn wound dressing. Int. J. Biol. Macromol. 2020, 164, 4193-4204. [CrossRef]

200. Pilicheva, B.; Uzunova, Y.; Bodurov, I.; Viraneva, A.; Exner, G.; Sotirov, S.; Yovcheva, T.; Marudova, M. Layer-by-layer selfassembly films for buccal drug delivery: The effect of polymer cross-linking. J. Drug Deliv. Sci. Technol. 2020, $59,101897$. [CrossRef]

201. Khare, T.; Mahalunkar, S.; Shriram, V.; Gosavi, S.; Kumar, V. Embelin-loaded chitosan gold nanoparticles interact synergistically with ciprofloxacin by inhibiting efflux pumps in multidrug-resistant Pseudomonas aeruginosa and Escherichia coli. Environ. Res. 2021, 199, 111321. [CrossRef] [PubMed]

202. Basu, S.K.; Kavitha, K.; Rupeshkumar, M. Evaluation of ionotropic cross-linked chitosan/gelatin B microspheres of tramadol hydrochloride. AAPS PharmSciTech 2011, 12, 28-34. [CrossRef] [PubMed]

203. Dawoud, M. Chitosan coated solid lipid nanoparticles as promising carriers for docetaxel. J. Drug Deliv. Sci. Technol. 2021, 62, 102409. [CrossRef]

204. Öztürk, A.A.; Kiyan, H.T. Treatment of oxidative stress-induced pain and inflammation with dexketoprofen trometamol loaded different molecular weight chitosan nanoparticles: Formulation, characterization and anti-inflammatory activity by using in vivo HET-CAM assay. Microvasc. Res. 2020, 128, 103961. [CrossRef] [PubMed]

205. Chen, M.C.; Huang, S.F.; Lai, K.Y.; Ling, M.H. Fully embeddable chitosan microneedles as a sustained release depot for intradermal vaccination. Biomaterials 2013, 34, 3077-3086. [CrossRef]

206. Chandrasekar, S.S.; Phanse, Y.; Hildebrand, R.E.; Hanafy, M.; Wu, C.W.; Hansen, C.H.; Osorio, J.E.; Suresh, M.; Talaat, A.M. Localized and systemic immune responses against SARS-COV-2 following mucosal immunization. Vaccines 2021, 9, 132. [CrossRef]

207. Gao, X.; Gong, J.; Cai, Y.; Wang, J.; Wen, J.; Peng, L.; Ji, H.; Jiang, S.; Guo, D. Chitosan modified squalene nanostructured lipid carriers as a promising adjuvant for freeze-dried ovalbumin vaccine. Int. J. Biol. Macromol. 2021, 188, 855-862. [CrossRef]

208. Moniz, T.; Costa Lima, S.A.; Reis, S. Marine polymeric microneedles for transdermal drug delivery. Carbohydr. Polym. 2021, 266, 118098. [CrossRef]

209. Kurakula, M.; Raghavendra, N. Prospection of recent chitosan biomedical trends: Evidence from patent analysis (2009-2020). Int. J. Biol. Macromol. 2020, 165, 1924-1938. [CrossRef] 